\title{
Review \\ Hedgehog/GLI Signaling Pathway: Transduction, Regulation, and Implications for Disease
}

\author{
Ashley N. Sigafoos, Brooke D. Paradise and Martin E. Fernandez-Zapico *(D)
}

Citation: Sigafoos, A.N.; Paradise, B.D.; Fernandez-Zapico, M.E. Hedgehog/GLI Signaling Pathway: Transduction, Regulation, and Implications for Disease. Cancers 2021, 13, 3410. https://doi.org/ $10.3390 /$ cancers 13143410

Academic Editors: Enrico De Smaele and Barbara Stecca

Received: 17 May 2021

Accepted: 5 July 2021

Published: 7 July 2021

Publisher's Note: MDPI stays neutral with regard to jurisdictional claims in published maps and institutional affiliations.

Copyright: (c) 2021 by the authors. Licensee MDPI, Basel, Switzerland. This article is an open access article distributed under the terms and conditions of the Creative Commons Attribution (CC BY) license (https:// creativecommons.org/licenses/by/ $4.0 /)$.
Schulze Center for Novel Therapeutics, Division of Oncology Research, Mayo Clinic, Rochester, MN 55905, USA; Sigafoos.Ashley@mayo.edu (A.N.S.); Paradise.Brooke@mayo.edu (B.D.P.)

* Correspondence: fernandezzapico.martin@mayo.edu

Simple Summary: The Hedgehog/GLI (Hh/GLI) pathway plays a major role during development and it is commonly dysregulated in many diseases, including cancer. This highly concerted series of ligands, receptors, cytoplasmic signaling molecules, transcription factors, and co-regulators is involved in regulating the biological functions controlled by this pathway. Activation of Hh/GLI in cancer is most often through a non-canonical method of activation, independent of ligand binding. This review is intended to summarize our current understanding of the Hh/GLI signaling, noncanonical mechanisms of pathway activation, its implication in disease, and the current therapeutic strategies targeting this cascade.

Abstract: The Hh/GLI signaling pathway was originally discovered in Drosophila as a major regulator of segment patterning in development. This pathway consists of a series of ligands (Shh, Ihh, and Dhh), transmembrane receptors (Ptch1 and Ptch2), transcription factors (GLI1-3), and signaling regulators (SMO, HHIP, SUFU, PKA, CK1, GSK3 $\beta$, etc.) that work in concert to repress (Ptch1, Ptch2, SUFU, PKA, CK1, GSK3 $\beta$ ) or activate (Shh, Ihh, Dhh, SMO, GLI1-3) the signaling cascade. Not long after the initial discovery, dysregulation of the Hh/GLI signaling pathway was implicated in human disease. Activation of this signaling pathway is observed in many types of cancer, including basal cell carcinoma, medulloblastoma, colorectal, prostate, pancreatic, and many more. Most often, the activation of the Hh/GLI pathway in cancer occurs through a ligand-independent mechanism. However, in benign disease, this activation is mostly ligand-dependent. The upstream signaling component of the receptor complex, SMO, is bypassed, and the GLI family of transcription factors can be activated regardless of ligand binding. Additional mechanisms of pathway activation exist whereby the entirety of the downstream signaling pathway is bypassed, and PTCH1 promotes cell cycle progression and prevents caspase-mediated apoptosis. Throughout this review, we summarize each component of the signaling cascade, non-canonical modes of pathway activation, and the implications in human disease, including cancer.

Keywords: hedgehog; cancer; GLI; SUFU; canonical and non-canonical activation; Hh pathway inhibitors

\section{The History of Hedgehog}

The first identified components of the Hh/GLI signaling pathway were fused and cubitus interruptus, the Drosophila homologue of the GLI family of transcription factors [1,2]. In 1980, Nusslein-Volhard and Wieschaus discovered the Hh ligand as part of their search for embryonic lethal mutants in Drosophila. The pair discovered 15 genetic loci implicated in segment patterning in Drosophila. When mutated, each locus produced distinct alterations in larvae patterning. The mutation in the Hh locus produced denticles on the body of the fly that were oriented in the opposite direction of non-mutants, indicating the importance of Hh in polarity and development in larvae. The resemblance of these mutants to a hedgehog inspired the name of this genetic locus. This study by Nusslein-Volhard and Wieschaus 
was foundational for the later characterization of the Hh signaling pathway, as they not only identified the Hh ligand but also identified Ptch1 as another Hh-related locus crucial for development [3].

Within the next two decades, scientists had thoroughly detailed the full DNA sequence of the Hh gene in Drosophila [4-6]. From this work, researchers found a remarkable sequence homology between the Drosophila Hh gene and that of vertebrates. First, the Sonic Hedgehog (Shh) ligand was characterized in chick embryos, and not long after, the three vertebral homologues, Shh, Indian Hedgehog (Ihh), and Desert Hedgehog (Dhh), were discovered $[7,8]$. It was not until the late 1990s that the GLI family of transcription factors was thought to be involved in the Hh signaling pathway [9-13]. Out of these discoveries came the thorough characterization of the Hh/GLI signaling cascade that we are most familiar with. GLI's major negative regulator, suppressor of fused (SUFU), had already been discovered at this point, but its direct interaction with the GLI family of transcription factors was still unknown. In his study, Préat et al. investigated the phenotypic effects of the fused protein and potential suppressors of this phenotype. This investigational team discovered SUFU as the mitigator of the fused mutant phenotype. The fused mutant Drosophila have alterations in segment patterns and often have ovarian tumors, but overexpression of SUFU abrogated these phenotypes [14]. By the early 2000s, many components of the signaling cascade had been discovered, and their interactions with each other were becoming known.

Along with the increasing understanding of the Hh/GLI signaling pathway components came insights into its role in physiology. From the outset, alterations in segment patterning in Drosophila caused by aberrant Hh/GLI signaling indicated a significant role of the Hh/GLI pathway in development [1-3,14]. Nusslein-Volhard and Wieschaus observed that mutations in Hh caused loss of ventral and bilateral patterning in larvae [3]. Mutations in the Hh/GLI signaling pathway leading to disruptions in patterning which ultimately affected normal development were confirmed by Préat in his study of fused [14]. Continued studies into the role of Hh/GLI signaling in development confirmed that this pathway was conserved in vertebrates, highlighting the importance of this signaling pathway, particularly the necessity for highly regulated and timed activation of this signaling pathway to facilitate normal embryonic development. The first indications of the involvement of the Hh/GLI signaling pathway in the development of vertebrates were in studies of the morphogenesis of the craniofacial complex. Mutations in Shh caused midline patterning defects in developing embryos that led to holoprosencephaly and cyclopia. Further studies into the role of the Hh/GLI pathway in the development of the head uncovered this pathway as essential for development of the frontonasal and maxillary processes. Even transient loss of Shh in this context is sufficient to cause cleft lip/palate and mold holoprosencephaly [15-18]. In addition to craniofacial development, the broader role of the Hh/GLI signaling pathway in embryonic development was being discovered. Aberrations in this signaling pathway were now being linked to defects in the brain, spinal cord, skeleton, and limbs [18,19].

Evidence for a role of the Hh/GLI signaling pathway in human disease was not defined until the late 1990s. The first implication was in basal cell nevus syndrome in $1996[20,21]$. Characteristics of this syndrome include formation of basal cell carcinomas and developmental abnormalities usually involving the skin, further emphasizing the importance of this signaling cascade in development [20-24]. Though this syndrome is associated with the development of tumors, the direct implication of the Hh/GLI signaling pathway in cancer came later. At this point, the Hh/GLI signaling pathway was implicated mostly in non-cancer diseases, such as holoprosencephaly and other craniofacial developmental defects, abnormal skeletal development, aberrations in the nerve sheath, and infertility [25-27]. More recently, this signaling cascade has been characterized as a major contributor to a wide variety of cancers, such as basal cell carcinoma, medulloblastoma, colorectal, prostate, pancreatic, and others [28-35].

By the early 2000s, researchers were beginning to appreciate the complexity of the Hh/GLI signaling pathway, not only on a molecular level, but also in terms of disease relevance. The pathway consists of a highly concerted series of interactions between lig- 
ands, receptors, transducers, co-regulators, and transcription factors, with the potential to function both as an autocrine and paracrine signaling cascade. Further, the vast network of target genes suggested a degree of responsiveness to cellular context inherent to this signaling pathway. From the outset, there was a considerable degree of complexity to the Hh/GLI signaling pathway that left some wondering whether this cascade should be considered as part of a network instead of an isolated signaling pathway [36,37]. To date, there have been 40 genes identified as involved in the Hh/GLI signaling pathway in Drosophila, while there are $56 \mathrm{Hh} / \mathrm{GLI}$ signaling pathway genes in mammalians [38]. Pathway components are continuing to be discovered as we learn more about the mechanisms and functions of this pathway and its complex nature.

\section{Hh/GLI Signaling Pathway Components}

The Hh/GLI signaling pathway is a highly regulated, concerted cascade of extracellular ligands, receptor proteins, cytoplasmic signaling molecules, transcription factors, co-regulators, and target genes (Figure 1). The interactions between components of this signaling pathway are spatiotemporally regulated to ensure activation of the pathway only in proper cellular and tissue context. Typically, the Hh/GLI signaling pathway remains in the off state in mature, adult cells. The activation of this signaling cascade is required for tissue development and homeostasis, and has a significant role in the maintenance of pluripotent and somatic stem cell populations in the skin, mammary tissue, prostate epithelium, neural tissue, exocrine pancreas, and lung epithelium [39-44]. Hh/GLI signaling is also temporarily activated in wound healing and tissue repair, where stem cell populations are actively contributing to tissue production [45]. This pathway is tightly regulated and repressed in developed tissues, and dysregulation can lead to developmental disorders and disease.

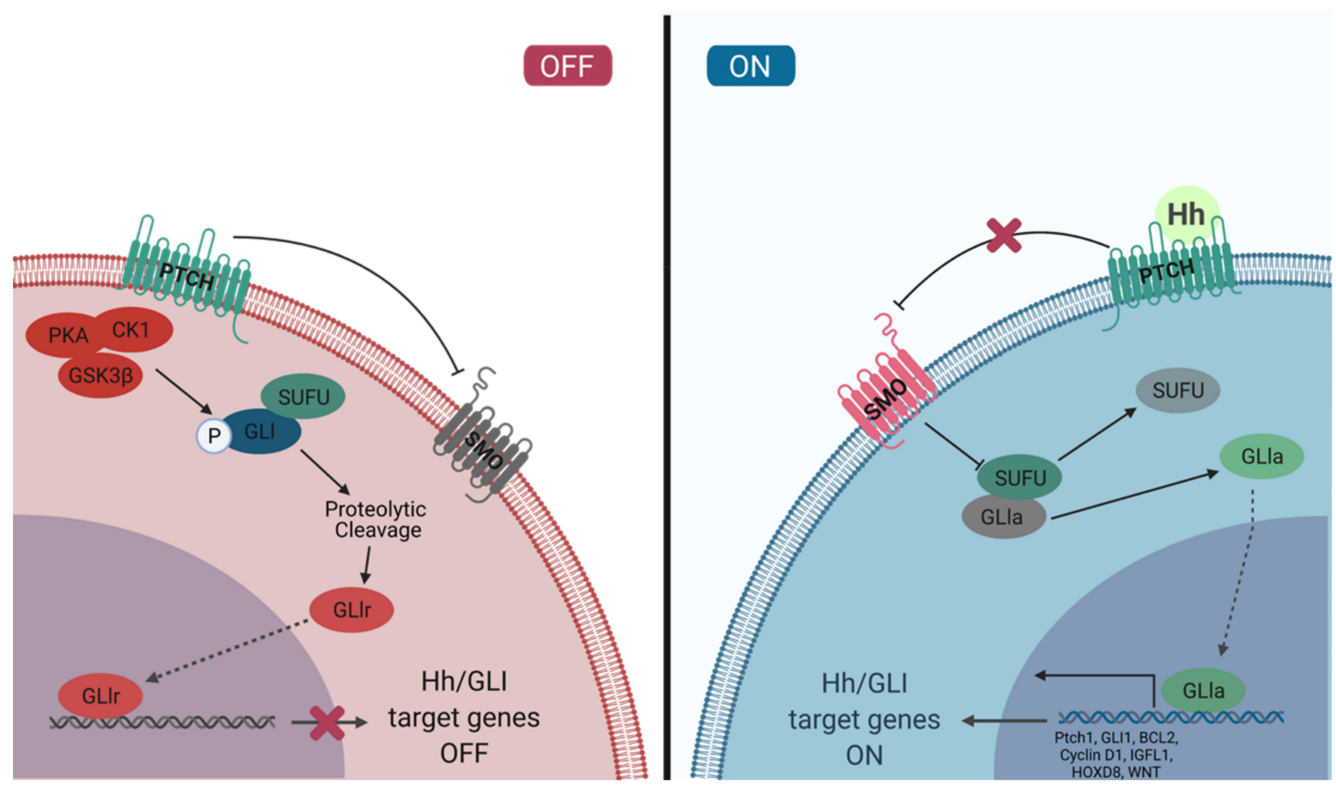

Figure 1. Activation of the Hh/GLI signaling pathway. Left panel: In the absence of ligand binding, PTCH exerts repressive effects on SMO. GLI transcription factors are sequestered by SUFU and phosphorylated by PKA, CK1, and GSK3 $\beta$, marking them for proteolytic cleavage. The cleavage of the C-terminal domain creates GLIr, the repressor form of the transcription factor. GLIr then translocates into the nucleus and represses the transcription of Hh/GLI target genes. Right panel: Hh ligand binding to the extracellular domain of PTCH inhibits the receptor, relieving the repressive effects on SMO. SMO then inhibits the sequestration by SUFU and phosphorylation by PKA, CK1, and GSK3 $\beta$, sparing GLI from proteolytic cleavage. The full-length form of GLI is a transcriptional activator that translocates into the nucleus and promotes the transcription of Hh/GLI target genes such as PTCH1, GLI1, BCL2, Cyclin D1, IGFL1, HOXD8, and WNT. The canonical Hh/GLI signaling pathway is most typically restricted to the primary cilium, however aberrant activation of this pathway may occur in alternate cellular compartments such as the cell membrane. 


\subsection{Extracellular Ligands}

In vertebrates, the Hh/GLI signaling pathway can be activated by Shh, Ihh, or Dhh. These extracellular ligands are lipid-modified proteins which, although they share high Nterminal sequence identity (76-91\%), carry out different developmental functions [46]. Dhh had the lowest sequence identity to either Shh or Ihh. Its function is typically associated with development of gonad tissue, specifically ovarian granulosa cells and testicular sertoli cells [47-49]. Shh and Ihh, which exhibit the highest sequence homology, have some shared functions in several tissues, yet their role in developmental regulation is mostly unique. Ihh is a major regulator of skeletal development, particularly in endochondral ossification $[8,50,51]$. Shh is critical in patterning in development, specifically implicated in dorsal-ventral neural tube patterning, anterior-posterior limb patterning, and brain, teeth, and foregut development [52-57]. Though similar, each ligand promotes tissue-specific and highly regulated activation of the Hh/GLI signaling pathway.

Perhaps the most unique characteristic of the Hh ligands is the post-translational modifications, including the addition of a cholesterol molecule to the $\mathrm{N}$-terminal domain which is required for activation and transport of the ligand between cells [58-60]. The Hh ligands are originally produced as precursor molecules [60-62]. First, approximately 25 amino acids are cleaved from the N-terminal domain of the $46 \mathrm{kDa}$ precursor molecule, removing the signal peptide. Then, the remaining protein is further cleaved into the 19 $\mathrm{kDa}$-terminal fragment $(\mathrm{N}-\mathrm{Hh})$ and the $25 \mathrm{kDa}$ C-terminal fragment $(\mathrm{C}-\mathrm{Hh})[25,62]$. This cleavage is mediated by an internal, autoproteolytic mechanism $[25,61,62]$. The Cterminal fragment has catalytic activity, whereby a cystine residue initiates a neutrophilic attack on the neighboring glycine residue in the $\mathrm{N}$-terminal fragment. This leaves a thioester, which is then attacked by a cholesterol, resulting in the covalent attachment of a cholesterol group to the C-terminal domain of $\mathrm{N}-\mathrm{Hh}[25,58]$. The cholesterol modification associates with the lipid in the cell membrane, tethering $\mathrm{N}-\mathrm{Hh}$ to the outside of the cell $[25,58,59]$. This association with the cell membrane facilitates the final processing step of the $\mathrm{N}-\mathrm{Hh}$ ligand: palmitoylation of the N-terminal domain by skinny Hedgehog acyltransferase (Ski) $[58,63,64]$. Not only is the cholesterol group important in facilitating the palmitoylation modification, but it has also been implicated in stabilizing $\mathrm{N}-\mathrm{Hh}$ and facilitating long-range transport of N-Hh for paracrine signaling [65-68]. Now that $\mathrm{N}-\mathrm{Hh}$ is dually modified, it is a fully activated signaling molecule. However, it is still tethered to the cell membrane of the secreting cell. The protein, Dispatched (Disp), is responsible for releasing the tethered ligand from the cell membrane as the final step in secreting the Hh ligand for activation of the signaling cascade $[25,58,69,70]$.

Though the fully modified ligand has been secreted, the simple release of the tethered ligand is not enough to create the highly regulated morphogen gradient that is required for $\mathrm{N}-\mathrm{Hh}$ to regulate development. For this, additional proteins and enzymes are required to chaperone the diffusion of the ligand. The heparan-sulfate-synthesizing enzyme, EXT, is required for the movement of $\mathrm{N}-\mathrm{Hh}[25,58,71-75]$. Heparan sulfate proteoglycan (HSPG) can by synthesized by EXT and localize to the cell surface, which can interact with NHh and lipoprotein lipophorin to facilitate the loading of Hh into soluble lipoproteins to facilitate the trafficking of the ligand [76,77]. An additional enzyme involved in mediating the release of N-Hh from the cell surface is Sulfatase1 (SULF1). Through its desulfation activity, SULF1 can disrupt the interaction between HSPGs at the cell surface. This can work to both repress or facilitate Hh/GLI signaling. SULF1 activity on the cell surface of the secreting cell will facilitate the release of N-Hh to stimulate signaling, whereas SULF1 activity on the cell surface of the receiving cell will disrupt ligand binding and repress the Hh/GLI signaling pathway $[77,78]$. N-Hh is characterized as the signaling domain, and through its interactions with various proteoglycans, enzymes, and lipoproteins, it will ultimately bind the cell surface receptors of the receiving cell to initiate Hh/GLI signaling. 


\subsection{Receptor Complex}

The Hh/GLI signaling pathway receptors are localized to the primary cilia (PC) in most tissues. This microtubule-based organelle emerges from the cell surface and is implicated in mediating and interpreting mechanical, chemical, and thermal signaling [79-81]. The role of the PC as the Hh/GLI signaling transduction hub is conserved from invertebrates to vertebrates [61-64]. The transmembrane Hh ligand receptor, Patched (Ptch), is located at the base of the PC [82]. In vertebrates, there are two homologs of this receptor, Patched 1 (PTCH1) and 2 (Ptch2). In the absence of Hh ligand binding, these two receptors are responsible for repressing the activity of Smoothened (SMO), a transmembrane signaling protein [83]. PTCH1 extracellular domain contains a sterol-sensing domain (SSD) which interacts with the cholesterol modification of the Hh ligands [84]. When Hh ligands are bound to PTCH1, the receptor is internalized and trafficked to the lysosome for degradation, thereby relieving its repressive effects on SMO $[85,86]$.

In the absence of PTCH1, SMO is phosphorylated by CK1 $\alpha$ and $\mathrm{G}$ protein-coupled receptor kinase 2 (GRK2). This activates $\mathrm{SMO}$ and promotes its translocation into the PC $[87,88]$. SMO translocation is mediated by $\beta$-arrestin and Kinesin-like protein Kif3A, which interact with kinesin family member 7 motor protein (Kif7) for transport [89-91]. The SMO- $\beta$-arrestin complex inhibits both cAMP-dependent PKA and CK1, blocking the phosphorylation and proteolytic cleavage of GLI2/3. The full-length GLI proteins are active and will translocate into the nucleus to promote transcription of Hh/GLI target genes [92-95]. Additional studies have shown that SMO is the source of an additional signal through engaging GTP-binding regulatory proteins (G protein) [96-99]. SMO can activate the $G_{i}$ family of $G$ proteins, which, in some cellular contexts, is required for the activation of GLI transcription factors $[96,98,99]$. The involvement of $G$ proteins in activating GLI transcription factors provides a partial explanation as to how Hh/GLI signaling can regulate such a wide variety of cellular functions. In recent years, SMO has also been shown to bind cholesterol, which activates the receptor and contributes to the Hh/GLI signal activation $[100,101]$. It is yet to be uncovered whether cholesterol binding is required for canonical activation of the Hh/GLI signaling pathway or if this is yet another mode through which Hh/GLI signaling can be activated, independent of the ligands.

PTCH1 is primarily expressed in mesenchymal cells, with Shh produced in neighboring epithelial cells, while Ptch2 is expressed mainly in testicular and skin epithelial cells $[102,103]$. Though both PTCH1 and Ptch2 are capable of binding all three Hh ligands, PTCH1 is considered to be the primary receptor [104]. Additionally, co-receptors have been identified that can modulate the activity of the Hh/GLI pathway. Boc, Cdon, and Growth-arrest-specific-1 (Gas1) can interact with the Hh ligands to ultimately activate the Hh/GLI signaling pathway [105-107]. On the other hand, co-receptors such as Hedgehoginteracting protein (Hhip) can negatively regulate the Hh/GLI signaling pathway. Hhip is a membrane glycoprotein that can bind all the Hh ligands, which prevents their interaction with PTCH1 and ultimately attenuates the signal [108]. Hhip is a target of the Hh/GLI signaling pathway and serves as part of the negative feedback loop, maintaining the balance of Hh/GLI signal activity [35,108]. Together, these receptors can increase or decrease Hh/GLI signaling, and are thought to regulate the level of activation of the Hh/GLI signaling cascade [109].

\subsection{The GLI Family of Transcription Factors}

Triggering of the Hh/GLI signaling pathway results in the activation of the GLI family of transcription factors to translate the extracellular ligand binding into a gene expression response. The GLI family of transcription factors can interact with each other and a variety of co-regulators to regulate specific subsets of gene targets based on those interactions. Though GLI1-3 have high sequence homology, they exhibit differences in tissue expression, transcriptional regulation, and binding partners. Not only does this increase the complexity of the signaling cascade, it also helps to explain how a single signaling cascade can have such a wide variety of transcriptional responses based on cellular and tissue context. 
The GLI family of transcription factors are a subfamily of the Krüppel family of transcription factors, which share a highly conserved zinc-finger domain for DNA binding $[94,110,111]$. GLI1-3 contain a 5-finger domain towards the center of each protein. Fingers 2-5 will recognize and bind the GACCACCCA motif, contacting the major groove and wrapping around the DNA. Finger one does not contact the DNA [112]. It is thought that the zinc fingers may also mediate protein-protein interactions [113]. Additionally, each of the GLI proteins has a nuclear localization signal (NLS), a nuclear export signal (NES), and SUFU binding domains [94]. GLI1 contains a single activation domain in the C-terminus and GLI2/3 contain 2 activation domains in the C-terminus, which interact with transcriptional activators to propagate the transcriptional activation effects of the GLI family of transcription factors (Figure 2) [94,114,115]. While GLI1-3 all contain C-terminal transactivation domains [94,116], only GLI2/3 contain an N-terminal repression domain, which contributes to their activity as transcriptional repressors $[10,94,114]$. The GLI proteins exhibit predominantly nuclear localization [111,117], and utilize both NLS-dependent and independent mechanisms. GLI2/3 each contain two NLS, one which is dependent on nuclear import machinery importin $\alpha / \beta$, while the other NLS is independent of this machinery and instead interacts with importin $\beta 2[94,118,119]$. The SUFU binding domain, SYGH, is common amongst GLI1-3 and is required for negative regulation by SUFU [118,120-122]. SUFU binding to this motif prevents recognition of the NLS on GLI, supporting the cytoplasmic sequestration of GLI [118,120-122].

A

\begin{tabular}{|l|l|l|l|l|l|l|l|l|l|}
\hline & & GLI1 & D & SB & ZF & NLS & D & NES & \\
\hline GLI2 & RD & & D & SB & ZF & NLS & D & NES & \\
\hline GLI3 & RD & D & SB & ZF & NLS & D & NES & TAD \\
\hline
\end{tabular}

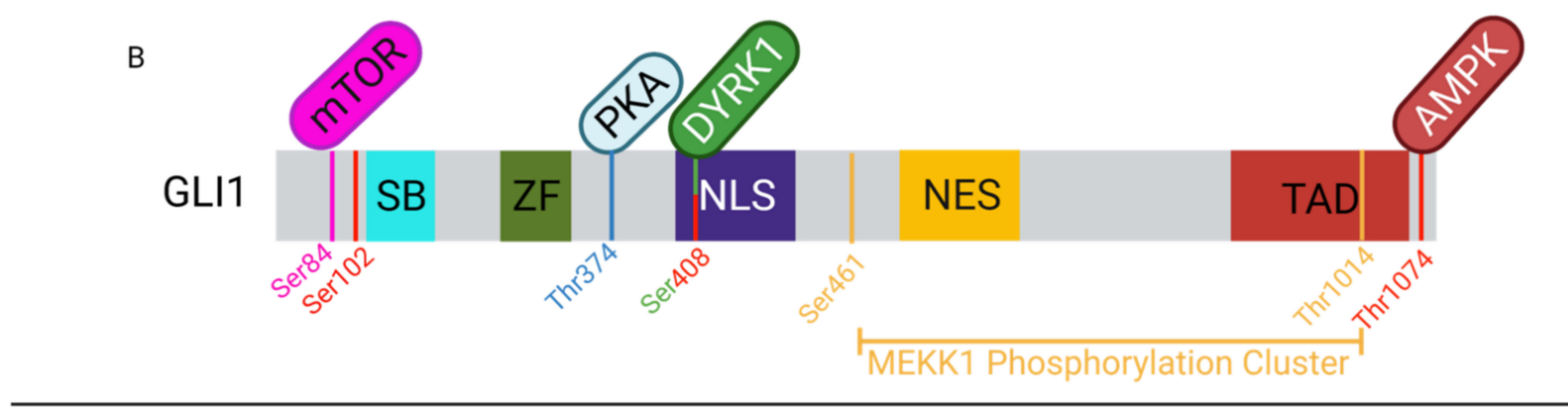

C

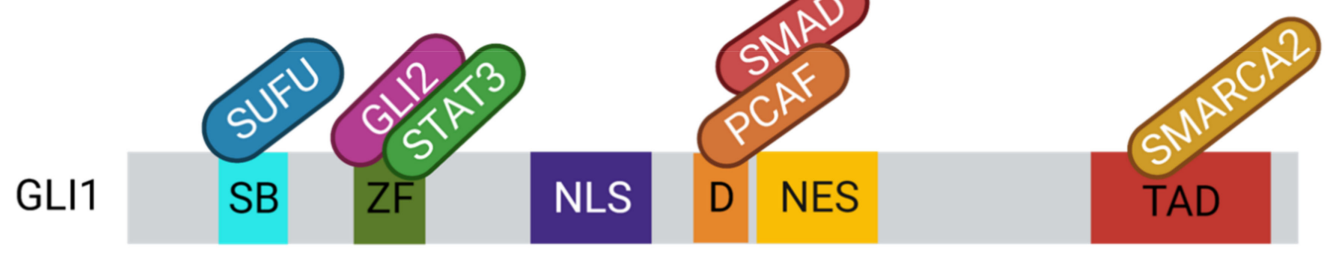

Figure 2. GLI1-3 regulatory and protein-interacting domains, post-translational modification sites, and interactions with co-regulators. (A) GLI1-3 proteins and their relevant regulatory sequences and protein-interacting domains. RD (blue) represents the repressor domain, D (orange) represents degron sequence, SB (cyan) represents the SUFU binding site, ZF (green) represents the zinc finger domain, NLS (purple) represents the nuclear localization signal, NES (yellow) represents the nuclear export signal, and TAD (red) represents the transcriptional activator domain. (B) GLI1 protein amino acids 
required for post-translation modifications. Serine 84 is recognized and phosphorylated by mTOR (pink). Serine 102, Serine 408, and Threonine 1074 are recognized and phosphorylated by AMPK (red). Threonine 374 is recognized and phosphorylated by PKA (blue). Serine 408 is also recognized and phosphorylated by DYRK1A (green). MEKK1 (yellow) recognizes and phosphorylates a series of amino acids between Serine 461 and Threonine 1014. (C) GLI1 protein-interacting domains for several co-regulators. SUFU (blue) binds the SUFU binding domain. GLI2 (purple) and STAT3 (green) can complex and bind to the zinc finger domain. PCAF (orange) and SMAD2/4 (red) can bind near the degron. SMARCA2 (yellow) can bind in the trans-activator domain.

GLI protein activity is regulated through various mechanisms. Internal regulatory sequences, post-translational modifications, and co-regulatory proteins all have a role in modulating GLI activity (Figure 2). GLI2/3 contain destruction signals, one localized to each terminus, that promote the rapid degradation of the protein and prevent cytoplasmic accumulation. The rapid turnover of the proteins prevents GLI transcriptional activation [123]. A specific set of post-translational modifications (PTMs) mark GLI2/3 for proteasomal degradation. In the Hh-off state, GLI2/3 will be phosphorylated by PKA on the P1-6 domain, which allows CK1 and GSK3 $\beta$ to recognize and further phosphorylate the proteins $[94,114,123-126]$. The phosphorylated GLIs can then be bound by $\beta \operatorname{TrCP}$, which facilitates ubiquitination by SCF $\beta \operatorname{TrCP}$ and promotes proteasomal degradation. The C-terminal end of GLI2/3 is cleaved, removing the activation domain and facilitating the transition into the repressor form $[10,30,124,125,127]$. When Hh/GLI signaling is active, GLI2/3 are not phosphorylated in this domain and are spared from proteasomal degradation. The proteolytic processing of GLI2 is not as efficient as it is for GLI3, therefore GLI2 is typically found in its full-length form [124]. GLI3 be found in the full-length form contributing to tumorigenesis, however not as often as GLI2 [128]. Similarly, GLI1 is not majorly regulated by proteasomal degradation. Instead, GLI1 activity is regulated at the transcriptional level and by cytoplasmic sequestration [10,116]. GLI1 is typically not expressed in Hh-off cells, but when the signal is perpetuated by GLI2/3, in their active forms, it can induce the expression of GLI1 to amplify the effects of Hh signaling [94,116,127]. Given that the proteolytic cleavage is most efficient in GLI3, it is not surprising that GLI3 is typically seen as the transcriptional repressor, while GLI1/2 are suggested to be the main transcriptional activators of the pathway $[114,116]$.

In addition to proteasomal degradation, GLI proteins can also be regulated through protein-protein interactions (Figure 2). GLI1-3 can bind with a variety of proteins, cytosolic and nuclear, which can affect their transcriptional activity. The most common mechanism of GLI repression is through SUFU binding. This negative regulator is thought to sequester GLI1-3 in the cytoplasm to prevent nuclear translocation and further transcriptional activation of Hh/GLI signaling pathway target genes [129]. Similarly, MEKK1 can phosphorylate the C-terminal domain of GLI1, promoting its association with 14-3-3, a cytoplasmic protein, thereby sequestering it in the cytoplasm and inhibiting nuclear translocation [130]. Another GLI protein interaction is with Missing in Metastasis (MIM), which can interact with the SUFU-GLI complex and facilitate the release of GLI1-3, enhancing transcriptional activation [131,132]. Additional proteins such as aPKC can bind with GLI-bound MIM complex and can further phosphorylate GLI1, leading to maximal DNA binding affinity and therefore maximizing the transcriptional activation via GLI1 [131]. Similarly, mTOR can promote GLI1 dissociation from SUFU by phosphorylating it, which simultaneously promotes nuclear translocation and enhances GLI1 activity [133]. The GLI proteins can also interact with other nuclear proteins to enhance transcriptional activation. GLI2/3 can interact with CBP/p300 via their C-terminal domain to promote transcription [134-136]. The histone acetyltransferase, PCAF, can interact with GLI1 in the promoter of target genes to promote open chromatin conformations and help facilitate transcription [137]. This PCAF-GLI1 interaction has also been observed in TGF $\beta$ signaling with the addition of SMAD2/4 to the complex [138]. Interestingly, PCAF may also negatively regulate the 
activity of GLI1 through its ubiquitin ligase activity. PCAF interaction with non-DNAbound GLI1 will result in ubiquitination of GLI1, ultimately targeting it for proteasomal degradation and inactivation $[139,140]$. SMARCA2 is yet another known co-activator of GLI1. The direct protein-protein interaction can facilitate an open chromatin conformation to promote transcriptional accessibility of target genes [141]. Similarly, SMARCA4 has been shown to interact with GLI1/3 to activate gene transcription and to interact with GLI3R to repress gene transcription through mediating an open or closed chromatin conformation, respectively [142]. Through their transactivation domain, GLI1/2 can interact with TAF9, a transcriptional co-activator, to enhance their transcriptional activity $[143,144]$. GLI1 has also been shown to interact with DYRK1A, which can enhance GLI1 transcriptional activity through two different mechanisms. First, DYRK1A can retain GLI1 in the nucleus [145], and DYRK1A may also phosphorylate GLI1, positively regulating its transcriptional activity $[94,116]$. DYRK2 carries out the opposite effect on GLI2, where phosphorylation of GLI2 targets the protein for proteasomal degradation, producing the repressor form of GLI2 [94]. Similarly, AMPK can phosphorylate GLI1 and target the protein for degradation, thereby inhibiting transcriptional activity. Within the nucleus, when GLI2/3 bind DNA in a repressive form, they can recruit histone deacetylases (HDAC) to the $\mathrm{N}$-terminal domain to promote chromatin remodeling and gene silencing in that region [94]. Interestingly, GLI interactions with HDACs have also been shown to mediate GLI induction of target genes as well, acting as positive regulators of GLI function [142,146]. GLI1 and GLI3 can interact with SOX9 in the promoters of genes involved in chondrocyte differentiation, and this interaction can both activate or repress target gene transcription based on cellular context [147]. In addition to the aforementioned interactions with co-activators and repressors, the GLI family of transcription factors can form dimers to regulate the transcription of a subset of Hh-responsive genes. GLI1 and GLI2 have been shown to physically interact, and depletion of GLI1 can inhibit GLI2 occupancy in some promoters (BCL2, MYCN, and CCND1), indicating that this interaction may be required for activation of a subset of GLIregulated genes [148]. The protein interactions and PTMs are numerous, each impacting GLI activity in a unique way and supporting the adaptability of this signaling pathway to cellular context.

The major negative regulator of the GLI family of transcription factors, SUFU, is a 484 amino acid protein that acts as a negative regulator of GLI1-3 [149]. SUFU can act as an adaptor protein, binding GLI1-3 and interacting with additional components of the cytoskeleton to sequester GLI or interacting with kinases to promote PTMs of GLI. It has also been suggested that SUFU acts as a chaperone in GLI1-3 nuclear translocation. Taken together, SUFU has a determining role in the cellular localization of GLI1-3, and this is the main mechanism through which SUFU carries out its regulatory effects on the GLI proteins [150]. Increasing evidence to support both theories suggests that SUFU may act through different mechanisms to regulate GLI activity $[118,151-153]$. SUFU localizes to both the cytoplasm and nucleus, and a recent study showed two of the mechanisms by which SUFU represses GLI1/2. For GLI1, SUFU piggybacks off of the CMR1-mediated nuclear export of GLI1 to promote cytoplasmic localization of GLI1 and repress its activity. For GLI2, SUFU uses a cytoplasmic tethering mechanism [154]. The latest characterization of the full-length SUFU demonstrated that this protein can alternate between an open and closed state, which is influenced by the presence or absence of GLI binding. The alternation between these states is conserved between human and Drosophila SUFU protein, indicating that this behavior is important for SUFU function. The $\mathrm{N}$ - and C-terminal domains of SUFU will come together to "sandwich" GLI and promote a stable interaction. It is suggested that GLI might mediate SUFU's conformational change from the open to closed state, interacting with both the $\mathrm{N}$ - and C-terminal domains and dragging them together. The closed state predominates when SUFU is negatively repressing GLI activity, and this conformation is inhibited when Hh/GLI signaling is active. GLI dissociation is promoted by Hh signaling, and SUFU takes on the open conformation, yet the mechanistic details of this dissociation are still unknown [153]. 
SUFU is an adaptor protein and interacts with both cytoplasmic and nuclear proteins. Most of the SUFU protein-protein interactions are with other negative regulators of transcription, however, there have been a few reports of SUFU interacting with positive regulators of transcription, though the nature of those interactions has not been fully characterized. SUFU can interact with SAP18, a component of the Sin3 co-repressor complex that recruits HDACs to remodel chromatin in promoter regions and decrease gene expression. SUFU, SAP18, and Sin3 cannot bind the DNA, but require the SUFU-GLI interaction to be recruited to GLI-responsive promoters [154-156]. SUFU can also interact with an E3 ligase, Skp1-Cul1, and an F-box protein, Fbxl17, which ubiquitinate SUFU upon Hh signaling and facilitate SUFU degradation within the nucleus [157]. This relieves SUFU repression of GLI and promotes transcriptional activation. SUFU interaction with PKA and GSK3 $\beta$ can prevent its nuclear degradation and stabilize Hh/GLI signaling. It was recently discovered that SUFU can interact with protein phosphatase 4 regulatory subunit 2 (Ppp4r2) to dephosphorylate it, leaving it susceptible to degradation via Skp1-Cul1 and Fbx117, driving the turnover of SUFU in the nucleus [150]. Lastly, Galectin 3, a partner of pCIP, was identified as another SUFU-interacting protein, suggesting that SUFU might be involved in mRNA maturation [154]. pCIP also has acetyl transferase activity and can interact with CBP and p300, indicating that SUFU may also be involved in the recruitment of proteins which facilitate gene transcription $[138,154]$. Nuclear SUFU can also interact with various regulatory proteins, including $p 66 \beta$ and Mycbp, which can negatively and positively regulate the functions of SUFU, respectively [158]. SUFU can interact with a variety of proteins which can influence its role as a repressor in the Hh/GLI signaling pathway.

The various degrees of cooperation between GLI1, 2, and 3 create a network of interaction commonly referred to as the GLI code. The interactions between these proteins are largely dictated by cellular context, and the repressor and activators can work together to create a spectrum of transcriptional responses [32,127]. Isoforms of each GLI protein have been characterized, and like GLI1-3, some of these isoforms exhibit additional tissue specificity. This contributes further to the various roles and cellular responses of Hh/GLI signaling, and promotes unique downstream effects based on tissue type or cellular context $[128,159,160]$. The GLI network is not yet fully understood, but there are a few contexts in which the interactions have been characterized relating to frog neuronal networks. Early studies of different combinations of GLI activity required for appropriate embryo patterning revealed that only GLI1 can induce floor plate differentiation, while only GLI2/3 were involved in skeletal patterning $[114,161]$. Further, GLI2/3 can inhibit GLI1 induction in the ventral forebrain and floor plate in developing frog embryos [162], while GLI3 can inhibit motoneuron induction by GLI2 in a different context [161]. These examples illustrate the context-dependence cooperation of GLIs that can ultimately affect GLI activity. The notion of a GLI network can help to explain some of the contradictory findings of GLI activity that we can otherwise not explain. This includes GLI3 having an alternate subset of gene targets in the presence or absence of GLI1, or GLI2/3 cooperation having opposite effects on GLI1 activity compared to GLI3 alone [32,127]. Further, GLI1 and 2 have some common targets, yet also have distinct subsets of gene targets, further supporting the idea of GLI cooperation ultimately affecting the transcriptional activity on target genes [163].

Another subfamily of the Krüppel family of proteins is the GLI-similar (GLIS) transcription factors. GLIS1-3 contain zinc-finger domains and are closely related to GLI1$3[111,164,165]$. Apart from the highly conserved zinc-finger domain, GLIS1-3 have relatively low sequence homology $[164,166-169]$. These proteins are localized to the primary cilium and can undergo nuclear translocation after activation via PTMs, similar to GLI1-3. Once inside the nucleus, GLIS1-3 can bind DNA through the zinc-finger domain and regulate transcription. GLIS can recognize and bind the GLI binding motif, which suggests the potential for interaction between these two subfamilies of Krüppel proteins [111,170]. When co-expressed, GLIS2 can inhibit reporter activity of GLI1 [170]. GLIS can act both as transcriptional activators and repressors, and have been shown to interact with CtBP1 to recruit histone modifiers and promote transcriptional repression [164]. GLIS are involved in 
a wide variety of cellular processes, including cell proliferation, apoptosis, differentiation, and development. The potential for crosstalk between GLIS1-3 and GLI1-3 increases the network of interaction described in the GLI code.

\subsection{Hh/GLI Signaling Pathway Target Genes}

The Hh/GLI signaling pathway is implicated in development, and typically, the target genes of this pathway are cell-type- and context-dependent. Many of the general gene targets of this pathway are developmental regulators, such as FGF4, Pax6-9, ABCG2, and Hhip, cell cycle regulators such as CCND2 and CCNE1, apoptosis regulator, BCL2, transcription factors FOXM1 and N-myc, and Wnt pathway proteins, JAG1, SFRP1, and Wnt $[4,108,171-176]$. In stem cells, Hh/GLI signaling can induce genes such as BMI1, LGR5, CD44, and CD133 through crosstalk with other signaling pathways such as Wnt. To promote epithelial-to-mesenchymal transition (EMT), the Hh/GLI signaling pathway can upregulate genes such as SNAI1, SNAI2, ZEB1, ZEB2, TWIST2, and FOXC2 [177]. Additionally, the Hh/GLI signaling pathway can induce the transcription of PTCH1 and Ptch2 as a form of pathway regulation [178]. Through direct induction of gene expression and interaction with various pathways, the Hh/GLI signaling pathway has a wide range of gene targets that can regulate cell cycle, promote differentiation and proliferation, EMT, and many more functions.

\section{Non-Canonical Activation of the Hh/GLI Signaling Pathway}

Typically, canonical pathway activation refers to extracellular ligand (Shh/Dhh/Ihh) binding PTCH1 and relieving repression of SMO to activate the downstream signaling cascade $[179,180]$. Though vitally important in development, canonical pathway activation is not widely implicated in disease. Instead, a non-canonical activation of the Hh/GLI signaling pathway, whereby SMO is bypassed, is a typical driver in disease. Non-canonical Hh/GLI pathway activation typically refers to SMO-independent activation, but sometimes more broadly includes ligand-independent pathway activation [180]. While Ptch1 is considered the primary $\mathrm{Hh}$ ligand binding target, other targets include Boc, Cdon, and Gas1. These interactions can activate the Hh/GLI signaling pathway independent of the Ptch1 receptor, as mentioned in the previous section. In addition, these receptors also play a critical role in other signaling pathways, such as myogenesis, axon guidance, CREB, ERK, GPCR, and apoptotic pathways, just to name a few [105-107]. While these binding targets can be considered part of the non-canonical activation of the Hh/GLI signaling pathway, there are two main mechanisms by which the signaling cascade can be activated to induce non-canonical Hh/GLI signaling. Type I is a SMO-independent mechanism and type II is a SMO-dependent mechanism that bypasses the GLI family of transcription factors.

In type I non-canonical Hh/GLI pathway activation, PTCH1 does not interact with the SMO receptor. Instead, PTCH1 is involved in the regulation of cell cycle and apoptosis through the caspase protein, and Shh ligand binding to the extracellular domain of PTCH1 can influence these interactions. In the unbound state, PTCH1 interacts with phosphorylated cyclin B1 [181,182]. PTCH1 can also recruit caspase-3, which will cleave a portion of the C-terminal domain of PTCH1. This cleavage will release caspase recruitment domain family member 8 (CARD) and adaptor protein found and a half LIM domains 2 (FHL2)/DRAL. This leads to the activation of caspase-9, which ultimately triggers apoptosis. When Shh binds to the extracellular domain of PTCH1, it inactivates the receptor and prevents this caspase-mediated apoptosis [182]. Moreover, cyclin B1 is released from the intracellular domain of the PTCH1 receptor and facilitates cell proliferation [181,182]. Type II non-canonical pathway activation is SMO-dependent, but does not rely on the GLI family of transcription factors to propagate its effects. In addition to promoting the active form of the GLI family of transcription factors, SMO also has functional G-protein coupled receptor (GPCR) properties with selectivity to heterotrimeric $G_{i}$ proteins, through which it carries out this type II non-canonical pathway activation [96,182]. When the Hh ligand binds and inactivates PTCH1, SMO is activated. SMO uses these $\mathrm{G}_{i}$ proteins to activate 
phosphoinositide 3-kinase (PI3K) kinase, small GTPases Ras homologous family member A (RhoA), and Ras-related C3 botulinum toxin substrate 1 (Rac1) [183]. The SMO-Rho cellular response is rapid and leads to the reconstruction of actin cytoskeleton along with stress fiber formation, tubulogenesis, and tumor-dependent angiogenesis [184]. In addition to activating PI3K, RhoA, and Rac1, $\mathrm{G}_{\mathrm{i}}$ proteins also promote $\mathrm{Ca}^{2+}$ influx into the cytosol. The Shh-SMO-G $\mathrm{G}_{\mathrm{i}}$ protein cascade activates phospholipase C (PLC) production, which increases PI3K and promotes opening of calcium channels in the smooth endoplasmic reticulum membrane, leading to a cytosolic spike in $\mathrm{Ca}^{2+}$ [185]. This $\mathrm{Ca}^{2+}$ influx affects differentiation, proliferation, apoptosis, and the migration of both neural and neuronal precursor cells [186,187]. Additionally, partial SMO agonists have demonstrated the ability to uncouple the SMO-Ampk-Ca ${ }^{2+}$ signaling axis from the Hh/GLI signaling pathway and drive metabolic changes favoring the Warburg effect [188]. Together, the effects of type II non-canonical Hh/GLI signaling pathway activation can lead to cytoskeletal reconstruction, angiogenesis, and proliferative effects, contributing to the progression of cancer.

Crosstalk between other signaling pathways is another way in which the Hh/GLI pathway can be activated independent of ligand binding. There are many reports of the TGF $\beta$, KRAS, and Wnt/ $\beta$-catenin pathways activating the downstream constituents of the Hh/GLI pathway (Figure 3) [189-201]. The TGF $\beta$ signaling pathway is one of the most well-characterized pathways to interact with the Hh/GLI signaling. This cascade consists of a family of ligands which bind to TGF $\beta$ receptor II and facilitate its dimerization and recruitment of the TGF $\beta$ receptor I dimer to form an active tetramer. This complex phosphorylates their intracellular domains to activate kinase activity, recruits the regulatory SMADs, and phosphorylates and activates them. The regulatory SMADs then dissociate from the receptor complex and bind co-SMADs, which then translocate into the nucleus to promote transcription of TGF $\beta$ target genes (Figure 3) [198]. The TGF $\beta$ signaling pathway has dual roles in cancer depending on cellular context, acting as either a tumor suppressor or tumor supporter. In its role as a tumor suppressor, it can activate genes involved in cell cycle arrest and apoptosis through a SMAD4-dependent mechanism [199]. As a tumor supporter, this pathway can activate genes involved in immune suppression, angiogenesis, and EMT. Vimentin and cadherins can be induced to promote EMT, and genes such as VEGF and MMP9 are consistently upregulated by the TGF $\beta$ signaling pathway to promote angiogenesis $[189,193,197,202,203]$. Activation of the TGF $\beta$ signaling pathway will also lead to recruitment of inflammatory cells $[189,193,197]$. Through release of paused RNAPII [204-212], the TGF $\beta$ signaling pathway can induce the transcription of the GLI family of transcription factors and thereby increase their activity, leading to non-canonical activation of the Hh/GLI signaling pathway [196,204,213]. GLI1-3 have been well-characterized as direct transcriptional targets of the canonical, SMAD-dependent TGF $\beta$ signaling pathway $[138,179,190,191,214]$. This regulation of the GLI transcription factors is independent of SMO $[190,215]$. In addition to regulation at the transcriptional level, it has been shown that the TGF $\beta$ signaling pathway can interfere with PKA phosphorylation of GLI1-3, modulating their activity by preventing their proteasomal degradation [216]. Additionally, the GLI family of transcription factors can interact with the SMAD transcription factors, both increasing their activity and promoting transcription of an additional cohort of tumorigenic genes [138]. The crosstalk between the TGF $\beta$ signaling pathway and the Hh/GLI signaling pathway may be essential for the TGF $\beta$ signaling pathway to carry out its full, tumor-supportive effects [217-219]. Further, the interaction between these two pathways seems to be cyclical in that the activation of the Hh/GLI pathway by TGF $\beta$ can ultimately promote the expression of genes that activate the TGF $\beta$ signaling pathway $[220,221]$. 


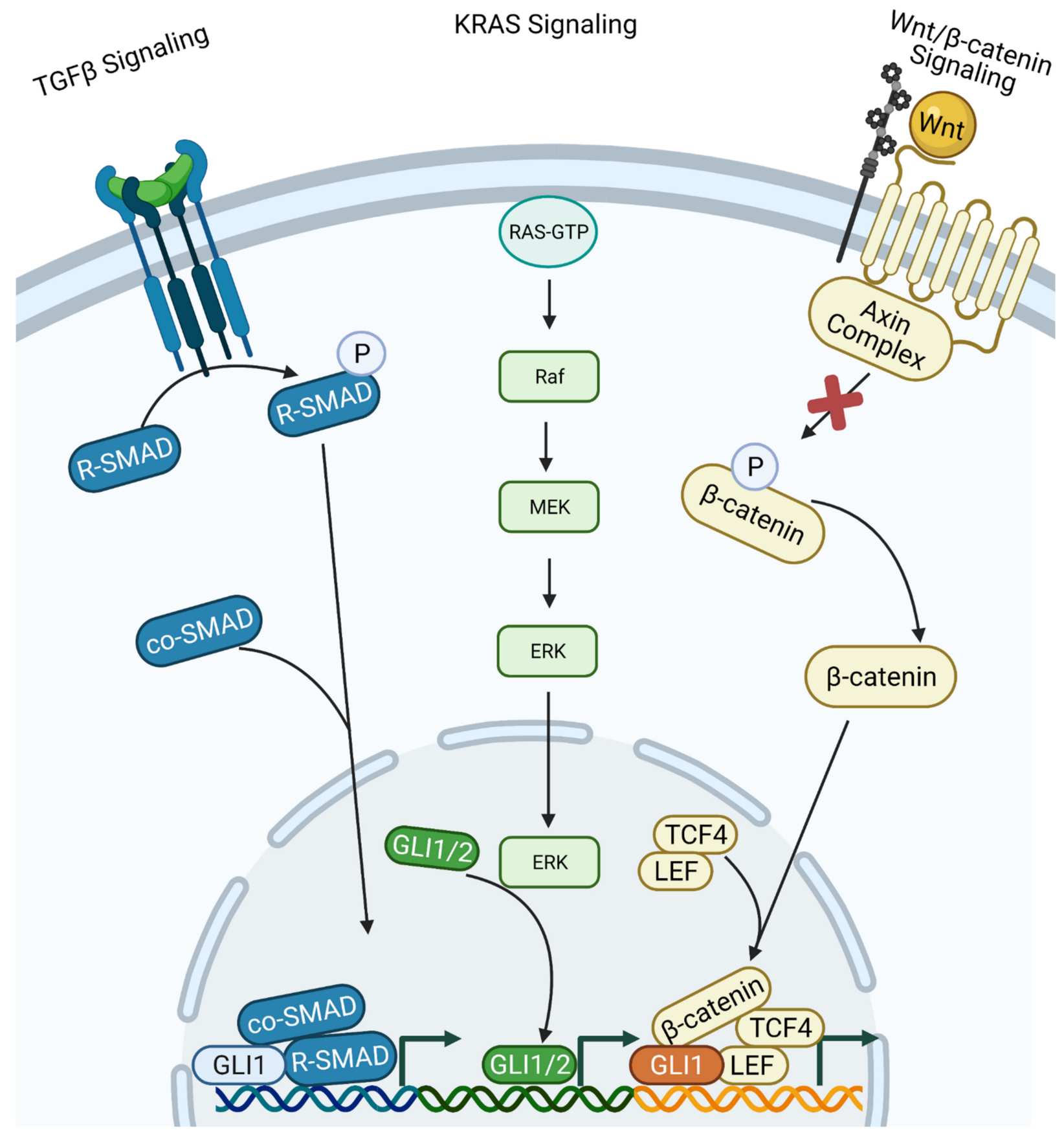

Figure 3. Non-canonical activation of the Hh/GLI pathway. TGF $\beta$ Signaling: Ligand binding in the extracellular domain induces the catalytic activity of the receptor on the intracellular domain. R-SMADs can be phosphorylated and complex with co-SMADs, then translocate into the nucleus. Inside the nucleus, SMADs can recruit and bind with GLI1 to activate the transcription of $\mathrm{Hh}$ /GLI target genes. KRAS signaling: Constitutively active KRAS will phosphorylate Raf, which in turn phosphorylates MEK, which then phosphorylates ERK. Activated ERK will then translocate into the nucleus and activate a variety of transcription factors, including GLI1/2. Wnt/ $\beta$-catenin: Extracellular Wnt ligand binding promotes sequestration of the Axin complex to the intracellular side of the receptor. This inhibits phosphorylation of $\beta$-catenin, allowing for its nuclear translocation and recruitment of additional transcription factors, including GLI1, for transcriptional activation. Figure created with BioRender.

The KRAS signaling pathway is another pathway that exhibits crosstalk with and activation of the Hh/GLI signaling cascade [180,200]. KRAS is a GTPase signal transducer protein that is commonly mutated in pancreatic ductal adenocarcinomas (PDACs), resulting 
in a constitutively active form of the protein. As such, KRAS is continually inducing the downstream signaling cascade Raf/MEK/ERK and promoting transcription of target genes (Figure 3). Active KRAS will recruit, phosphorylate, and activate RAF, which in turn will phosphorylate MEK. Active MEK can then bind and phosphorylate ERK to activate it and promote nuclear translocation. Inside the nucleus, ERK will activate transcription factors such and Jun or Fos to induce transcription of target genes [222-224]. Studies have shown that the constitutive activation of the KRAS signaling pathway can lead to increased GLI1 transcriptional activity $[192,194,196]$. Further investigations showed that MEK can activate GLI1 activity, promoting Hh/GLI signaling [225]. Additionally, GLI1 and GLI2 are transcriptional targets of the KRAS signaling pathway, similar to the TGF $\beta$ signaling pathway. Increased mRNA transcription will lead to increased protein translation and further accumulation of the proteins in the cytoplasm, eventually increasing their transcriptional activity $[196,201]$.

The Wnt/ $\beta$-catenin signaling pathway is a non-canonical activator of the Hh/GLI pathway through transcriptional regulation and protein-protein interactions. When Wnt signaling is off, cytoplasmic $\beta$-catenin is degraded through a similar mechanism as the GLI family of transcription factors. The Axin complex, which contains CK1 and GSK3 $\beta$, will phosphorylate $\beta$-catenin in the absence of Wnt signaling, promoting the proteasomal degradation of $\beta$-catenin. The turnover of $\beta$-catenin in the cytoplasm prevents nuclear translocation, inhibiting the transcription of Wnt target genes. When Wnt binds to the Frizzled receptor, the receptor complexes with LRP6, and together, the complex recruits and sequesters the Axin complex, inhibiting its kinase activity. $\beta$-catenin can then accumulate in the cytoplasm, translocate into the nucleus, and bind either TCF or LEF to activate target genes (Figure 3) [226-228]. GLI2 transcription can be induced by $\beta$-catenin in a similar manner as the TGF $\beta$ signaling pathway $[190,229]$. Not only are GLI $1 / 2$ transcriptionally activated by $\beta$-catenin, but they can also form complexes with $\beta$-catenin in a similar manner as with the SMAD transcription factors [230]. Hh/GLI and Wnt/ $\beta$-catenin pathways also share similar regulatory molecules, including SUFU, CK1, and GSK3 $\beta$, indicating another mode for interaction $[195,230]$. There is some evidence to show that these two pathways may also interact in a cyclical manner, given that Wnt transcription can be activated by the GLI transcription factors [177,178]. Further, GLI3 can act in an inhibitor manner of some $\beta$-catenin targets, emphasizing that the interaction between these two pathways can be complex and bidirectional [231].

\section{The Hh/GLI Signaling Pathway in Disease}

The Hh/GLI signaling pathway is essential for regulating many developmental processes. It comes as no surprise that mutations, loss of function, or aberrant activation of the pathway can lead to developmental defects and disease $[33,34,180,194]$. For example, according to the Human Gene Mutation Database (HGMD), there are over two-hundred mutations (missense/nonsense, splicing, insertions/deletions, rearrangements, etc.) that can occur in the SHH gene that lead to deleterious effects. One of the most common diseases associated with mutations in the $\mathrm{SHH}$ gene is a developmental malformation known as holoprosencephaly [232]. In this disease, the brain is unable to divide properly into the right and left hemisphere. Severity of the disease can vary widely among effected individuals, with symptoms ranging from hypotelorism, microcephaly, hydrocephalus (causing macrocephaly) cleft palate, cyclopia, and proboscis [233]. Unsurprisingly, the physical distortion due to holoprosencephaly leads to other impairments, such as developmental delay, intellectual disability, seizures, inability to regulate temperature, and feeding difficulties, just to name a few [233]. Other developmental malformations due to Hh ligand mutations include radial hemimelia, polydactyly, cleft lip, bone development disease, and osteochondrodysplasia. Mutations in other pathway components such as PTCH1, SMO, and SUFU can lead to developmental malformations, including brachydactyly, Curry-Jones Syndrome, and Ellis-Can Creveld Syndrome, respectively [234]. 
While mutations play a crucial role in the aberrant Hh pathway leading to a plethora of developmental malformations, they can also lead to cancer. The pathway activators (Hh ligands, SMO, and GLI1-3) are considered proto-oncogenes due to their ability to upregulate the pathway and promote tumorigenesis. There are different mechanisms whereby the canonical Hh/GLI pathway can by dysregulated, leading to unwarranted activation. Ligand-independent activation of the signaling cascade increases the activity of GLI1-3, upregulating the expression of Hh/GLI pathway target genes. This type of pathway activation is commonly seen in Gorlin Syndrome, which is associated with the development of medulloblastomas, basal cell carcinomas, and rhabdomyosarcomas [20,235]. Additional mechanisms of aberrant pathway activation can be ligand-dependent, autocrine activation of the pathway, whereby cancer cells can upregulate the synthesis of the Shh ligand and stimulate Hh/GLI pathway activation. This type of pathway activation is common in prostate cancer, hepatocellular carcinoma, pancreatic cancer, and non-small cell lung cancer [236-240]. The Shh ligand can also be secreted by tumor cells and can participate in paracrine signaling, activating the Hh/GLI signaling pathway in both tumor and stromal cells, often seen in pancreatic and prostate cancers [34,235,241,242]. Lastly, tumor stroma can secrete the Shh ligand in a reverse paracrine mechanism, whereby the ligand will activate the Hh/GLI signaling pathway within tumor cells [243]. In some contexts, this paracrine signaling from the stroma can have a role in restraining tumor progression, further complicating the role of Hh/GLI signaling in cancer progression [241,242]. Each mechanism outlined above involves changes in the activity of Hh/GLI pathway constituents, classifying these as canonical mechanisms of pathway activation.

The repressors of the pathway (SUFU and PTCH1) are considered tumor suppressors, as their loss of function upregulates the Hh/GLI signaling activity to drive tumorigenesis $[31,35,116,244,245]$. It was not until recently that SUFU mutations were noted as potential drivers of disease. However, in a short time span, it has become increasingly clear that SUFU mutations have a significant impact in causing disease [23,24,30,244,246-249]. The involvement of the Hh signaling pathway in Gorlin Syndrome has been established previously, however, it was not until a study in 2018 that the contributions of SUFU mutations to this syndrome were brought to light. Gorlin Syndrome predisposes individuals to the development of basal cell carcinomas. Mutations in PTCH1 are linked to 85\% of cases of Gorlin Syndrome, however a subset of 5\% of cases exhibit deleterious mutations in SUFU. These mutations arise from an abnormal splice site which leads to loss of function of SUFU. Individuals with this mutation exhibit many characteristics of Gorlin Syndrome, but they also experience palmar sclerotic fibromas, which seems to be unique to this subset of patients. Further investigation into this subset of patients has revealed that SUFU gene mutations may actually cause a distinct cutaneous cancer predisposition syndrome that, while extremely similar to, is different from Gorlin Syndrome. Additional studies would be required in order to validate this observation [244]. Meningiomas resultant of Gorlin Syndrome or Familial multiple meningioma and childhood medulloblastomas have also been associated with SUFU mutations [244,246]. Additional studies in meningiomas identified a germline point mutation in SUFU present in a subset of patients. This mutation impacted the tertiary structure of SUFU, thereby impacting its tumor-suppressor function [246]. A nonsense mutation in SUFU was discovered in a subset of patients with nevoid basal cell carcinomas (as in Gorlin Syndrome). This mutation decreased the tumor-suppressor function of SUFU, similar to that in the subset of meningiomas previously described [23]. A similar cancer subtype, Merkel cell carcinoma, has been associated with SUFU mutation as a contributor to disease progression [30].

A study of patients with multiple hereditary infundibulocystic basal cell carcinoma syndrome was conducted to determine the role of SUFU mutations in disease progression. Individuals with the germline splice mutation resulted in not only the abolishment of SUFU protein, but it was also enough to place the individuals at higher risk for hereditary infundibulocystic basal cell carcinoma syndrome [24]. Another study determined the effects of both germline and somatic mutations in SUFU, and found that children with a splice 
mutation (causing a deletion of exon 6) presented with facial papules and dysmorphology due to this non-functioning SUFU protein [247]. In pancreatic cancer, a germline mutation in SUFU was found associated with intraductal papillary mucosal neoplasms (IPMNs) and elevated risk of pancreatic carcinomas. Given the correlation of increased IPMNs subsequently leading to PDAC, researchers found that patients with IPMNs in addition to a subset of germline mutations, including this SUFU mutation, were at higher risk of further developing pancreatic carcinomas than those with IPMNs and none of the identified germline mutations [248]. Lastly, a transcript variant of SUFU that contained a new and additional protein coding exon was identified in patients with PDAC. This mutation was correlated with increased metastasis in these PDAC patients [249].

In addition to the canonical activation of the Hh/GLI signaling pathway, non-canonical mechanisms of pathway activation have been implicated in disease. As previously described, the KRAS signaling pathway can result in overexpression of Hh/GLI target genes through interaction with and activation of GLI transcription factors. This non-canonical Hh/GLI pathway activation has been observed in many types of disease, including pancreatic ductal adenocarcinoma, melanoma, gastric cancer, colon cancer, lung cancers, multiple myelomas, and many more [192,196,201,250-254]. The TGF $\beta$ signaling pathway can similarly induce the expression of Hh/GLI target genes through SMAD transcription factor association with and activation of GLI transcription factors. Additionally, GLI1/2 transcription are induced by the TGF $\beta$ signaling pathway, ultimately leading to increased expression of Hh/GLI target genes. This TGF $\beta$-mediated pathway activation is noted in pancreatic cancer, gastric cancer, and colon cancer, to name a few $[138,190,255,256]$. Lastly, we discussed the role of Wnt/ $\beta$-catenin in promoting the transcription of Hh/GLI pathway target genes. This type of pathway activation is common in basal cell carcinomas, intestinal cancer, colon cancer, leukemia, brain tumors, ovarian cancer, and many more cancer subtypes $[178,198,219,228,230,257,258]$.

This profound effect in tumor biology has triggered the development of Hh/GLI inhibitors for cancer treatment. Presently, most therapies in targeting the Hh pathway have been focused on developing SMO inhibitors (SMOi). Some of the therapeutics include sonidegib, vismodegib, saridegib, BMS-833923, taladegib, and glasdegib [259,260]. There has been some success in treating basal cell carcinoma, myeloid malignancies, medulloblastoma, and a few other advanced solid tumors using SMOi therapeutics [261-266]. Unfortunately, the rapid accumulation of mutations in cancer has created a resistance to SMOi treatments, typically through acquisition of the D437H mutation in SMO [267,268]. This acquired SMOi resistance has given rise to research investigating other oncogenic drivers as potential therapeutic targets. This redirection of research led to downstream Hh activators such as GLI as potential therapeutic targets. In 2007, Lauth et al. showed via in vitro and in vivo models that molecules GANT61 and GANT58 were able to block DNA binding of GLI and therefore reduce proliferation and tumor growth [269]. Another molecule, Glabrescione B, was also tested and found to interfere with GLI1 ability to bind to DNA, and therefore inhibited the growth of Hedgehog-dependent tumors [270]. Researchers also explored Hedgehog pathway inhibitors (HPIs), such as HPI1, HPI2, HPI3, HPI4, and arsenic trioxide (ATO) [271-273]. Interestingly, each of the HPI's were observed to target different mechanisms of the pathway, with HPI1 inhibiting endogenous and exogenous GLI1/GLI2 activity [271], while HPI2 and HPI3 were observed blocking the ability of fulllength GLI2 conversion into transcription activators [271], leaving HPI4 to target the cilia, ultimately disrupting ciliogenesis from occurring, which inhibits proper ciliary progression and trafficking that is required for Hh/GLI function [271]. Lastly, ATO was observed to inhibit GLI1 protein function in the nucleus, while also reducing GLI2 ability to traffic and accumulate to the cilia, resulting in reduced Hh activity [272,273]. Despite GLI inhibitors demonstrating reduced proliferation or tumor growth through their interference of DNA binding, trafficking, processing, accumulation, or activation of GLI, they were unfortunately short-lived due to significant cytotoxicity observed in in vitro studies. Research is now turning to alternative pathways that focus on the non-canonical GLI activation molecules. 
Combinations of SMOi and additional pathway constituent inhibitors provide the most hope of impairing Hh/GLI pathway activation in solid tumors and preventing acquired resistance [260].

\section{Concluding Remarks}

The Hh/GLI signaling pathway is a highly regulated complex cascade of ligands, receptors, transcriptional effectors, and regulatory proteins. Its initial discovery in Drosophila provided the first insights into its role in regulating development. Aberrations in the Hh/GLI signaling pathway can lead to developmental defects and disease, including cancer. Further studies into the pathway have demonstrated that not only mutations lead to increased Hh/GLI signaling observed in disease, but there is also an additional subset of pathway interactions and non-canonical mechanisms of pathway activation that are significant contributors to the altered activity observed in disease.

Author Contributions: Conceptualization, A.N.S., B.D.P., and M.E.F.-Z.; writing-original draft preparation, A.N.S. and B.D.P.; writing—review and editing, A.N.S., B.D.P., and M.E.F.-Z.; supervision, M.E.F.-Z.; funding acquisition, M.E.F.-Z. All authors have read and agreed to the published version of the manuscript.

Funding: This research was funded by CA136526, to M.E.F.-Z.

Institutional Review Board Statement: Not Applicable.

Informed Consent Statement: Not Applicable.

Data Availability Statement: Data sharing not applicable. No new data were created or analyzed in this work.

Acknowledgments: We thank Terry Stephenson for her secretarial assistance.

Conflicts of Interest: The authors declare no conflict of interest.

\section{References}

1. Counce, S.J. Studies on female-sterility genes inDrosophila melanogaster. Z. Indukt. Abstamm. Vererb. 1956, 87, 443-461. [CrossRef]

2. Lindsley, D.L.; Grell, E.H. Genetic Variations of Drosophila Melanogaster, 627th ed.; Carnegie Institution of Washington Publication: Washington, DC, USA, 1983.

3. Nüsslein-Volhard, C.; Wieschaus, E. Mutations affecting segment number and polarity in Drosophila. Nature 1980, $287,795-801$. [CrossRef] [PubMed]

4. $\quad$ Ekker, S.; Jackson, D.; Von Kessler, D.; Sun, B.; Young, K.; Beachy, P.; Ekker, S.; Jackson, D.; Von Kessler, D.; Sun, B.; et al. The degree of variation in DNA sequence recognition among four Drosophila homeotic proteins. EMBO J. 1994, 13, 3551-3560. [CrossRef]

5. Mohler, J.; Vani, K. Molecular organization and embryonic expression of the hedgehog gene involved in cell-cell communication in segmental patterning of Drosophila. Development 1992, 115, 957-971. [CrossRef] [PubMed]

6. Ramírez-Weber, F.-A.; Kornberg, T.B. Cytonemes: Cellular Processes that Project to the Principal Signaling Center in Drosophila Imaginal Discs. Cell 1999, 97, 599-607. [CrossRef]

7. Levin, M.; Johnson, R.L.; Sterna, C.D.; Kuehn, M.; Tabin, C. A molecular pathway determining left-right asymmetry in chick embryogenesis. Cell 1995, 82, 803-814. [CrossRef]

8. St-Jacques, B.; Hammerschmidt, M.; McMahon, A.P. Indian hedgehog signaling regulates proliferation and differentiation of chondrocytes and is essential for bone formation. Genes Dev. 1999, 13, 2072-2086. [CrossRef]

9. Ding, Q.; Motoyama, J.; Gasca, S.; Mo, R.; Sasaki, H.; Rossant, J.; Hui, C. Diminished Sonic hedgehog signaling and lack of floor plate differentiation in Gli2 mutant mice. Development 1998, 125, 2533-2543. [CrossRef]

10. Ding, Q.; Fukami, S.-I.; Meng, X.; Nishizaki, Y.; Zhang, X.; Sasaki, H.; Dlugosz, A.; Nakafuku, M.; Hui, C.-C. Mouse Suppressor of fused is a negative regulator of Sonic hedgehog signaling and alters the subcellular distribution of Gli1. Curr. Biol. 1999, 9, 1119-S1. [CrossRef]

11. Karlstrom, R.O.; Talbot, W.S.; Schier, A.F. Comparative synteny cloning of zebrafish you-too: Mutations in the Hedgehog target gli2 affect ventral forebrain patterning. Genes Dev. 1999, 13, 388-393. [CrossRef] [PubMed]

12. Matise, M.; Epstein, D.; Park, H.; Platt, K.; Joyner, A. Gli2 is required for induction of floor plate and adjacent cells, but not most ventral neurons in the mouse central nervous system. Development 1998, 125, 2759-2770. [CrossRef]

13. Sasaki, H.; Hui, C.; Nakafuku, M.; Kondoh, H. A binding site for Gli proteins is essential for HNF-3beta floor plate enhancer activity in transgenics and can respond to Shh in vitro. Development 1997, 124, 1313-1322. [CrossRef] 
14. Préat, T.; Thérond, P.; Lamour-Lsnard, C.; Limbourg-Bouchon, B.; Tricoire, H.; Erk, I.; Mariol, M.-C.; Busson, D. A putative serine/threonine protein kinase encoded by the segment-polarity fused gene of Drosophila. Nature 1990, 347, 87-89. [CrossRef] [PubMed]

15. Hu, D.; Helms, J. The role of sonic hedgehog in normal and abnormal craniofacial morphogenesis. Development 1999, 126, 4873-4884. [CrossRef]

16. Belloni, E.; Muenke, M.; Roessler, E.; Traverse, G.; Siegel-Bartelt, J.; Frumkin, A.; Mitchell, H.; Donis-Keller, H.; Helms, C.; Hing, A.; et al. Identification of Sonic hedgehog as a candidate gene responsible for holoprosencephaly. Nat. Genet. 1996, 14, 353-356. [CrossRef] [PubMed]

17. Roessler, E.; Belloni, E.; Gaudenz, K.; Jay, P.; Berta, P.; Scherer, S.W.; Tsui, L.-C.; Muenke, M. Mutations in the human Sonic Hedgehog gene cause holoprosencephaly. Nat. Genet. 1996, 14, 357-360. [CrossRef] [PubMed]

18. Chiang, C.; Litingtung, Y.; Lee, E.; Young, K.E.; Corden, J.L.; Westphal, H.; Beachy, P.A. Cyclopia and defective axial patterning in mice lacking Sonic hedgehog gene function. Nature 1996, 383, 407-413. [CrossRef] [PubMed]

19. Anderson, E.; Peluso, S.; Lettice, L.A.; Hill, R.E. Human limb abnormalities caused by disruption of hedgehog signaling. Trends Genet. 2012, 28, 364-373. [CrossRef]

20. Hahn, H.; Wicking, C.; Zaphiropoulos, P.G.; Gailani, M.R.; Shanley, S.; Chidambaram, A.; Vorechovsky, I.; Holmberg, E.; Unden, A.B.; Gillies, S.; et al. Mutations of the Human Homolog of Drosophila patched in the Nevoid Basal Cell Carcinoma Syndrome. Cell 1996, 85, 841-851. [CrossRef]

21. Johnson, R.L.; Rothman, A.L.; Xie, J.; Goodrich, L.V.; Bare, J.W.; Bonifas, J.M.; Quinn, A.G.; Myers, R.M.; Cox, D.R.; Epstein, E.H.; et al. Human Homolog of patched, a Candidate Gene for the Basal Cell Nevus Syndrome. Science 1996, 272, 1668-1671. [CrossRef] [PubMed]

22. Atwood, S.; Sarin, K.; Whitson, R.J.; Li, J.R.; Kim, G.; Rezaee, M.; Ally, M.S.; Kim, J.; Yao, C.; Chang, A.L.S.; et al. Smoothened Variants Explain the Majority of Drug Resistance in Basal Cell Carcinoma. Cancer Cell 2015, 27, 342-353. [CrossRef] [PubMed]

23. Kijima, C.; Miyashita, T.; Suzuki, M.; Oka, H.; Fujii, K. Two cases of nevoid basal cell carcinoma syndrome associated with meningioma caused by a PTCH1 or SUFU germline mutation. Fam. Cancer 2012, 11, 565-570. [CrossRef] [PubMed]

24. Schulman, J.M.; Oh, D.H.; Sanborn, J.Z.; Pincus, L.; McCalmont, T.H.; Cho, R.J. Multiple Hereditary Infundibulocystic Basal Cell Carcinoma Syndrome Associated With a GermlineSUFUMutation. JAMA Dermatol. 2016, 152, 323-325. [CrossRef]

25. Jeong, J.; McMahon, A.P. Cholesterol modification of Hedgehog family proteins. J. Clin. Investig. 2002, 110, 591-596. [CrossRef]

26. McMahon, A.P.; Ingham, P.W.; Tabin, C.J. Developmental roles and clinical significance of Hedgehog signaling. Curr. Top. Dev. Biol. 2003, 53, 1-114. [CrossRef]

27. Ingham, P.W. Hedgehog signaling in animal development: Paradigms and principles. Genes Dev. 2001, 15, 3059-3087. [CrossRef] [PubMed]

28. Bailey, J.M.; Swanson, B.J.; Hamada, T.; Eggers, J.P.; Singh, P.K.; Caffery, T.; Ouellette, M.M.; Hollingsworth, M.A. Sonic Hedgehog Promotes Desmoplasia in Pancreatic Cancer. Clin. Cancer Res. 2008, 14, 5995-6004. [CrossRef] [PubMed]

29. Carballo, G.B.; Honorato, J.R.; de Lopes, G.P. A highlight on Sonic hedgehog pathway. Cell Commun. Signal. 2018, 16, 1-15. [CrossRef]

30. Cohen, P.R.; Kurzrock, R. Merkel Cell Carcinoma with a Suppressor of Fused (SUFU) Mutation: Case Report and Potential Therapeutic Implications. Dermatol. Ther. 2015, 5, 129-143. [CrossRef]

31. Doheny, D.; Manore, S.G.; Wong, G.L.; Lo, H.-W. Hedgehog Signaling and Truncated GLI1 in Cancer. Cells 2020, 9, 2114. [CrossRef]

32. Nguyen, V.; Chokas, A.L.; Stecca, B.; Altaba, A.R.I. Cooperative requirement of the Gli proteins in neurogenesis. Development 2005, 132, 3267-3279. [CrossRef] [PubMed]

33. Sari, I.N.; Phi, L.T.H.; Jun, N.; Wijaya, Y.T.; Lee, S.; Kwon, H.Y. Hedgehog Signaling in Cancer: A Prospective Therapeutic Target for Eradicating Cancer Stem Cells. Cells 2018, 7, 208. [CrossRef] [PubMed]

34. Skoda, A.M.; Simovic, D.; Karin, V.; Kardum, V.; Vranic, S.; Serman, L. The role of the Hedgehog signaling pathway in cancer: A comprehensive review. Bosn. J. Basic Med. Sci. 2018, 18, 8-20. [CrossRef] [PubMed]

35. Varjosalo, M.; Taipale, J. Hedgehog: Functions and mechanisms. Genes Dev. 2008, 22, 2454-2472. [CrossRef]

36. Cohen, J.M.M. The hedgehog signaling network. Am. J. Med. Genet. 2003, 123, 5-28. [CrossRef]

37. Ogden, S.K.; Ascano, M.; Stegman, M.; Robbins, D.J. Regulation of Hedgehog signaling: A complex story. Biochem. Pharmacol. 2004, 67, 805-814. [CrossRef]

38. Kanehisa, M. Toward understanding the origin and evolution of cellular organisms. Protein Sci. 2019, 28, 1947-1951. [CrossRef]

39. Fendrich, V.; Esni, F.; Garay, M.V.R.; Feldmann, G.; Habbe, N.; Jensen, J.; Dor, Y.; Stoffers, D.; Leach, S.D.; Maitra, A. Hedgehog Signaling Is Required for Effective Regeneration of Exocrine Pancreas. Gastroenterology 2008, 135, 621-631.e8. [CrossRef]

40. Lee, M.Y.; Sun, L.; Veltmaat, J.M. Hedgehog and Gli Signaling in Embryonic Mammary Gland Development. J. Mammary Gland. Biol. Neoplasia 2013, 18, 133-138. [CrossRef]

41. Locker, M.; Agathocleous, M.; Amato, M.A.; Parain, K.; Harris, W.A.; Perron, M. Hedgehog signaling and the retina: Insights into the mechanisms controlling the proliferative properties of neural precursors. Genes Dev. 2006, 20, 3036-3048. [CrossRef]

42. Watkins, D.N.; Berman, D.M.; Burkholder, S.G.; Wang, B.; Beachy, P.A.; Baylin, S.B. Hedgehog signalling within airway epithelial progenitors and in small-cell lung cancer. Nat. Cell Biol. 2003, 422, 313-317. [CrossRef] 
43. Zhang, J.; Lipinski, R.J.; Gipp, J.J.; Shaw, A.K.; Bushman, W. Hedgehog pathway responsiveness correlates with the presence of primary cilia on prostate stromal cells. BMC Dev. Biol. 2009, 9, 50. [CrossRef]

44. Zhou, J.-X.; Jia, L.-W.; Liu, W.-M.; Miao, C.-L.; Liu, S.; Cao, Y.-J.; Duan, E.-K. Role of sonic hedgehog in maintaining a pool of proliferating stem cells in the human fetal epidermis. Hum. Reprod. 2006, 21, 1698-1704. [CrossRef] [PubMed]

45. Le, H.; Kleinerman, R.; Lerman, O.Z.; Brown, D.; Galiano, R.; Gurtner, G.C.; Warren, S.M.; Levine, J.P.; Saadeh, P.B. Hedgehog signaling is essential for normal wound healing. Wound Repair Regen. 2008, 16, 768-773. [CrossRef]

46. Pathi, S.; Pagan-Westphal, S.; Baker, D.P.; Garber, E.A.; Rayhorn, P.; Bumcrot, D.; Tabin, C.J.; Pepinsky, R.B.; Williams, K.P. Comparative biological responses to human Sonic, Indian, and Desert hedgehog. Mech. Dev. 2001, 106, 107-117. [CrossRef]

47. Bitgood, M.J.; Shen, L.; McMahon, A.P. Sertoli cell signaling by Desert hedgehog regulates the male germline. Curr. Biol. 1996, 6, 298-304. [CrossRef]

48. Wijgerde, M.; Ooms, M.; Hoogerbrugge, J.W.; Grootegoed, J.A. Hedgehog Signaling in Mouse Ovary: Indian Hedgehog and Desert Hedgehog from Granulosa Cells Induce Target Gene Expression in Developing Theca Cells. Endocrinology 2005, 146, 3558-3566. [CrossRef]

49. Yao, H.-C.H.; Whoriskey, W.; Capel, B. Desert Hedgehog/Patched 1 signaling specifies fetal Leydig cell fate in testis organogenesis. Genes Dev. 2002, 16, 1433-1440. [CrossRef] [PubMed]

50. Chung, U.-I.; Schipani, E.; McMahon, A.P.; Kronenberg, H.M. Indian hedgehog couples chondrogenesis to osteogenesis in endochondral bone development. J. Clin. Investig. 2001, 107, 295-304. [CrossRef]

51. Vortkamp, A.; Lee, K.; Lanske, B.; Segre, G.V.; Kronenberg, H.M.; Tabin, C.J. Regulation of Rate of Cartilage Differentiation by Indian Hedgehog and PTH-Related Protein. Science 1996, 273, 613-622. [CrossRef] [PubMed]

52. Ahlgren, S.C.; Bronner-Fraser, M. Inhibition of Sonic hedgehog signaling in vivo results in craniofacial neural crest cell death. Curr. Biol. 1999, 9, 1304-1314. [CrossRef]

53. Briscoe, J.; Chen, Y.; Jessell, T.M.; Struhl, G. A Hedgehog-Insensitive Form of Patched Provides Evidence for Direct Long-Range Morphogen Activity of Sonic Hedgehog in the Neural Tube. Mol. Cell 2001, 7, 1279-1291. [CrossRef]

54. Britto, J.; Tannahill, D.; Keynes, R.J. A critical role for sonic hedgehog signaling in the early expansion of the developing brain. Nat. Neurosci. 2002, 5, 103-110. [CrossRef]

55. Dahmane, N.; Ruiz-I-Altaba, A. Sonic hedgehog regulates the growth and patterning of the cerebellum. Development 1999, 126, 3089-3100. [CrossRef] [PubMed]

56. Duprez, D.; Fournier-Thibault, C.; Le Douarin, N.; Duprez, D.; Fournier-Thibault, C.; Le Douarin, N. Sonic Hedgehog induces proliferation of committed skeletal muscle cells in the chick limb. Development 1998, 125, 495-505. [CrossRef] [PubMed]

57. Litingtung, Y.; Lei, L.; Westphal, H.; Chiang, C. Sonic hedgehog is essential to foregut development. Nat. Genet. 1998, 20 , 58-61. [CrossRef]

58. Varjosalo, M.; Taipale, J. Hedgehog signaling. J. Cell Sci. 2007, 120, 3-6. [CrossRef]

59. López, L.A.; Zuñiga, J.; Arrieta, O.; Ávila-Moreno, F. The Hedgehog-GLI pathway in embryonic development and cancer: Implications for pulmonary oncology therapy. Oncotarget 2017, 8, 60684-60703. [CrossRef]

60. Porter, J.A.; Young, K.E.; Beachy, P.A. Cholesterol Modification of Hedgehog Signaling Proteins in Animal Development. Science 1996, 274, 255-259. [CrossRef]

61. Lee, J.J.; Ekker, S.C.; Von Kessler, D.P.; Porter, J.A.; Sun, B.I.; Beachy, P.A. Autoproteolysis in hedgehog protein biogenesis. Science 1994, 266, 1528-1537. [CrossRef]

62. Bumcrot, D.A.; Takada, R.; McMahon, A.P. Proteolytic processing yields two secreted forms of sonic hedgehog. Mol. Cell. Biol. 1995, 15, 2294-2303. [CrossRef] [PubMed]

63. Pepinsky, R.B.; Zeng, C.; Wen, D.; Rayhorn, P.; Baker, D.P.; Williams, K.P.; Bixler, S.A.; Ambrose, C.M.; Garber, E.A.; Miatkowski, K.; et al. Identification of a Palmitic Acid-modified Form of Human Sonic hedgehog. J. Biol. Chem. 1998, 273, 14037-14045. [CrossRef]

64. Chamoun, Z.; Mann, R.K.; Nellen, D.; Von Kessler, D.P.; Bellotto, M.; Beachy, P.A.; Basler, K. Skinny Hedgehog, an Acyltransferase Required for Palmitoylation and Activity of the Hedgehog Signal. Science 2001, 293, 2080-2084. [CrossRef]

65. Lewis, P.M.; Dunn, M.; McMahon, J.A.; Logan, M.; Martin, J.F.; St-Jacques, B.; McMahon, A.P. Cholesterol Modification of Sonic Hedgehog Is Required for Long-Range Signaling Activity and Effective Modulation of Signaling by Ptc1. Cell 2001, 105, 599-612. [CrossRef]

66. Zeng, X.; Goetz, J.A.; Suber, L.M.; Jr, W.J.S.; Schreiner, C.M.; Robbins, D.J. A freely diffusible form of Sonic hedgehog mediates long-range signalling. Nat. Cell Biol. 2001, 411, 716-720. [CrossRef]

67. Callejo, A.; Torroja, C.; Quijada, L.; Guerrero, I. Hedgehog lipid modifications are required for Hedgehog stabilization in the extracellular matrix. Development 2006, 133, 471-483. [CrossRef] [PubMed]

68. Gallet, A.; Rodriguez, R.; Ruel, L.; Therond, P.P. Cholesterol Modification of Hedgehog Is Required for Trafficking and Movement, Revealing an Asymmetric Cellular Response to Hedgehog. Dev. Cell 2003, 4, 191-204. [CrossRef]

69. Burke, R.; Nellen, D.; Bellotto, M.; Hafen, E.; Senti, K.-A.; Dickson, B.J.; Basler, K. Dispatched, a Novel Sterol-Sensing Domain Protein Dedicated to the Release of Cholesterol-Modified Hedgehog from Signaling Cells. Cell 1999, 99, 803-815. [CrossRef]

70. Zhu, A.J.; Scott, M.P. Incredible journey: How do developmental signals travel through tissue? Genes Dev. 2004, 18, $2985-2997$. [CrossRef] [PubMed] 
71. The, I.; Bellaiche, Y.; Perrimon, N. Hedgehog Movement Is Regulated through tout velu-Dependent Synthesis of a Heparan Sulfate Proteoglycan. Mol. Cell 1999, 4, 633-639. [CrossRef]

72. Takei, Y.; Ozawa, Y.; Sato, M.; Watanabe, A.; Tabata, T. ThreeDrosophilaEXT genes shape morphogen gradients through synthesis of heparan sulfate proteoglycans. Development 2004, 131, 73-82. [CrossRef]

73. Nybakken, K.; Perrimon, N. Heparan sulfate proteoglycan modulation of developmental signaling in Drosophila. Biochim. Biophys. Acta BBA-Gen. Subj. 2002, 1573, 280-291. [CrossRef]

74. Han, C.; Belenkaya, T.Y.; Khodoun, M.; Tauchi, M.; Lin, X.; Lin, X. Distinct and collaborative roles ofDrosophilaEXT family proteins in morphogen signalling and gradient formation. Development 2004, 131, 1563-1575. [CrossRef] [PubMed]

75. Bellaiche, Y.; The, I.; Perrimon, N. Tout-Velu is a Drosophila Homologue of the Putative Tumour Suppressor EXT-1 and is Needed for Hh Diffusion. Nature 1998, 394, 85-88. [CrossRef]

76. Eugster, C.; Panakova, D.; Mahmoud, A.; Eaton, S. Lipoprotein-Heparan Sulfate Interactions in the Hh Pathway. Dev. Cell 2007, 13, 57-71. [CrossRef] [PubMed]

77. Ramsbottom, S.A.; Pownall, M.E. Regulation of Hedgehog Signalling Inside and Outside the Cell. J. Dev. Biol. 2016, 4, 23. [CrossRef]

78. Wojcinski, A.; Nakato, H.; Soula, C.; Glise, B. DSulfatase-1 fine-tunes Hedgehog patterning activity through a novel regulatory feedback loop. Dev. Biol. 2011, 358, 168-180. [CrossRef]

79. Moussaif, M.; Sze, J.Y. Intraflagellar Transport/Hedgehog-Related Signaling Components Couple Sensory Cilium Morphology and Serotonin Biosynthesis in Caenorhabditis elegans. J. Neurosci. 2009, 29, 4065-4075. [CrossRef] [PubMed]

80. Plotnikova, O.V.; Golemis, E.; Pugacheva, E.N. Cell Cycle-Dependent Ciliogenesis and Cancer. Cancer Res. 2008, 68, $2058-2061$. [CrossRef]

81. Goetz, S.C.; Ocbina, P.J.; Anderson, K.V. The primary cilium as a Hedgehog signal transduction machine. Methods Cell Biol. 2009, 94, 199-222. [CrossRef]

82. Rohatgi, R.; Milenkovic, L.; Scott, M.P. Patched1 Regulates Hedgehog Signaling at the Primary Cilium. Science 2007, 317, 372-376. [CrossRef]

83. Zaphiropoulos, P.G.; Undén, A.B.; Rahnama, F.; Hollingsworth, R.E.; Toftgard, R. PTCH2, a novel human patched gene, undergoing alternative splicing and up-regulated in basal cell carcinomas. Cancer Res. 1999, 59, 787-792. [PubMed]

84. Ingham, P.; Nystedt, S.; Nakano, Y.; Brown, W.; Stark, D.; Heuvel, M.V.D.; Taylor, A. Patched represses the Hedgehog signalling pathway by promoting modification of the Smoothened protein. Curr. Biol. 2000, 10, 1315-1318. [CrossRef]

85. Chen, Y.; Struhl, G. Dual Roles for Patched in Sequestering and Transducing Hedgehog. Cell 1996, 87, 553-563. [CrossRef]

86. Incardona, J.P.; Lee, J.H.; Robertson, C.P.; Enga, K.; Kapur, R.P.; Roelink, H. Receptor-mediated endocytosis of soluble and membrane-tethered Sonic hedgehog by Patched-1. Proc. Natl. Acad. Sci. USA 2000, 97, 12044-12049. [CrossRef]

87. Chen, Y.; Sasai, N.; Ma, G.; Yue, T.; Jia, J.; Briscoe, J.; Jiang, J. Sonic Hedgehog Dependent Phosphorylation by CK1 $\alpha$ and GRK2 Is Required for Ciliary Accumulation and Activation of Smoothened. PLoS Biol. 2011, 9, e1001083. [CrossRef]

88. Jia, J.; Tong, C.; Wang, B.; Luo, L.; Jiang, J. Hedgehog signalling activity of Smoothened requires phosphorylation by protein kinase A and casein kinase I. Nat. Cell Biol. 2004, 432, 1045-1050. [CrossRef]

89. Goetz, S.C.; Anderson, K. The primary cilium: A signalling centre during vertebrate development. Nat. Rev. Genet. 2010, 11, 331-344. [CrossRef]

90. Huangfu, D.; Liu, A.; Rakeman, A.S.; Murcia, N.S.; Niswander, L.; Anderson, K.V. Hedgehog signalling in the mouse requires intraflagellar transport proteins. Nature 2003, 426, 83-87. [CrossRef]

91. Kovacs, J.J.; Whalen, E.J.; Liu, R.; Xiao, K.; Kim, J.; Chen, M.; Wang, J.; Chen, W.; Lefkowitz, R.J. $\beta$-Arrestin-Mediated Localization of Smoothened to the Primary Cilium. Science 2008, 320, 1777-1781. [CrossRef]

92. Johnson, R.L.; Milenkovic, L.; Scott, M.P. In Vivo Functions of the Patched Protein: Requirement of the C Terminus for Target Gene Inactivation but Not Hedgehog Sequestration. Mol. Cell 2000, 6, 467-478. [CrossRef]

93. Marigo, V.; Tabin, C.J. Regulation of patched by sonic hedgehog in the developing neural tube. Proc. Natl. Acad. Sci. USA 1996, 93, 9346-9351. [CrossRef]

94. Niewiadomski, P.; Niedziółka, S.M.; Markiewicz, Ł.; Uśpieński, T.; Baran, B.; Chojnowska, K. Gli Proteins: Regulation in Development and Cancer. Cells 2019, 8, 147. [CrossRef] [PubMed]

95. Arveseth, C.D.; Happ, J.T.; Hedeen, D.S.; Zhu, J.-F.; Capener, J.L.; Shaw, D.K.; Deshpande, I.; Liang, J.; Xu, J.; Stubben, S.L.; et al. Smoothened transduces Hedgehog signals via activity-dependent sequestration of PKA catalytic subunits. PLoS Biol. 2021, 19, e3001191. [CrossRef]

96. Riobo, N.A.; Saucy, B.; DiLizio, C.; Manning, D.R. Activation of heterotrimeric G proteins by Smoothened. Proc. Natl. Acad. Sci. USA 2006, 103, 12607-12612. [CrossRef]

97. Shen, F.; Cheng, L.; Douglas, A.E.; Riobo, N.A.; Manning, D.R. Smoothened Is a Fully Competent Activator of the Heterotrimeric G Protein Gi. Mol. Pharmacol. 2013, 83, 691-697. [CrossRef] [PubMed]

98. DeCamp, D.L.; Thompson, T.M.; de Sauvage, F.J.; Lerner, M.R. Smoothened Activates Gai-mediated Signaling in Frog Melanophores. J. Biol. Chem. 2000, 275, 26322-26327. [CrossRef] [PubMed]

99. Kasai, K.; Takahashi, M.; Osumi, N.; Sinnarajah, S.; Takeo, T.; Ikeda, H.; Kehrl, J.; Itoh, G.; Arnheiter, H. The G12 family of heterotrimeric $G$ proteins and Rho GTPase mediate Sonic hedgehog signalling. Genes Cells 2004, 9, 49-58. [CrossRef] 
100. Huang, P.; Nedelcu, D.; Watanabe, M.; Jao, C.; Kim, Y.; Liu, J.; Salic, A. Cellular Cholesterol Directly Activates Smoothened in Hedgehog Signaling. Cell 2016, 166, 1176-1187.e14. [CrossRef]

101. Luchetti, G.; Sircar, R.; Kong, J.H.; Nachtergaele, S.; Sagner, A.; Byrne, E.F.; Covey, D.F.; Siebold, C.; Rohatgi, R. Cholesterol activates the G-protein coupled receptor Smoothened to promote Hedgehog signaling. eLife 2016, 5, e20304. [CrossRef]

102. Carpenter, D.; Stone, D.M.; Brush, J.; Ryan, A.; Armanini, M.; Frantz, G.; Rosenthal, A.; de Sauvage, F.J. Characterization of two patched receptors for the vertebrate hedgehog protein family. Proc. Natl. Acad. Sci. USA 1998, 95, 13630-13634. [CrossRef]

103. Motoyama, J.; Liu, J.; Mo, R.; Ding, Q.; Post, M.; Hui, C.-C. Essential function of Gli2 and Gli3 in the formation of lung, trachea and oesophagus. Nat. Genet. 1998, 20,54-57. [CrossRef]

104. Gailani, M.R.; Ståhle-Bäckdahl, M.; Leffell, D.J.; Glyn, M.; Zaphiropoulos, P.G.; Undén, A.B.; Dean, M.; Brash, D.E.; Bale, A.E.; Toftgård, R. The role of the human homologue of Drosophila patched in sporadic basal cell carcinomas. Nat. Genet. 1996, 14, 78-81. [CrossRef] [PubMed]

105. Allen, B.L.; Tenzen, T.; McMahon, A.P. The Hedgehog-binding proteins Gas1 and Cdo cooperate to positively regulate Shh signaling during mouse development. Genes Dev. 2007, 21, 1244-1257. [CrossRef] [PubMed]

106. Martinelli, D.C.; Fan, C.-M. Gas1 extends the range of Hedgehog action by facilitating its signaling. Genes Dev. 2007, 21, 1231-1243. [CrossRef]

107. Tenzen, T.; Allen, B.L.; Cole, F.; Kang, J.-S.; Krauss, R.S.; McMahon, A.P. The Cell Surface Membrane Proteins Cdo and Boc Are Components and Targets of the Hedgehog Signaling Pathway and Feedback Network in Mice. Dev. Cell 2006, 10, 647-656. [CrossRef] [PubMed]

108. Chuang, P.-T.; McMahon, A.P. Vertebrate Hedgehog signalling modulated by induction of a Hedgehog-binding protein. Nat. Cell Biol. 1999, 397, 617-621. [CrossRef]

109. Jeong, J.; McMahon, A.P. Growth and pattern of the mammalian neural tube are governed by partially overlapping feedback activities of the hedgehog antagonists patched 1 and Hhip1. Development 2005, 132, 143-154. [CrossRef] [PubMed]

110. Kinzler, K.W.; Ruppert, J.M.; Bigner, S.H.; Vogelstein, B. The GLI gene is a member of the Kruppel family of zinc finger proteins. Nat. Cell Biol. 1988, 332, 371-374. [CrossRef]

111. Ruppert, J.M.; Kinzler, K.W.; Wong, A.J.; Bigner, S.H.; Kao, F.T.; Law, M.L.; Seuanez, H.N.; O’Brien, S.J.; Vogelstein, B. The GLI-Kruppel family of human genes. Mol. Cell. Biol. 1988, 8, 3104-3113. [CrossRef]

112. Pavletich, N.P.; Pabo, C.O. Crystal structure of a five-finger GLI-DNA complex: New perspectives on zinc fingers. Science 1993, 261, 1701-1707. [CrossRef]

113. Koyabu, Y.; Nakata, K.; Mizugishi, K.; Aruga, J.; Mikoshiba, K. Physical and Functional Interactions between Zic and Gli Proteins. J. Biol. Chem. 2001, 276, 6889-6892. [CrossRef] [PubMed]

114. Altaba, A.R.I. Gli Proteins Encode Context-Dependent Positive and Negative Functions: Implications for Development and Disease. Development 1999, 123, 3205-3216. [CrossRef]

115. Yoon, J.W.; Liu, C.Z.; Yang, J.T.; Swart, R.; Iannaccone, P.; Walterhouse, D. GLI Activates Transcription through a Herpes Simplex Viral Protein 16-Like Activation Domain. J. Biol. Chem. 1998, 273, 3496-3501. [CrossRef]

116. Kasper, M.; Regl, G.; Frischauf, A.-M.; Aberger, F. GLI transcription factors: Mediators of oncogenic Hedgehog signalling. Eur. J. Cancer 2006, 42, 437-445. [CrossRef] [PubMed]

117. Kinzler, K.W.; Vogelstein, B. The GLI gene encodes a nuclear protein which binds specific sequences in the human genome. Mol. Cell. Biol. 1990, 10, 634-642. [CrossRef]

118. Barnfield, P.C.; Zhang, X.; Thanabalasingham, V.; Yoshida, M.; Hui, C.-C. Negative regulation of Gli1 and Gli2 activator function by Suppressor of fused through multiple mechanisms. Differentiation 2005, 73, 397-405. [CrossRef] [PubMed]

119. Torrado, B.; Graña, M.; Badano, J.L.; Irigoín, F. Ciliary Entry of the Hedgehog Transcriptional Activator Gli2 Is Mediated by the Nuclear Import Machinery but Differs from Nuclear Transport in Being Imp- $\alpha$ / $\beta 1$-Independent. PLoS ONE 2016, 11, e0162033. [CrossRef]

120. Kogerman, P.; Grimm, T.; Kogerman, L.; Krause, D.R.; Undén, A.B.; Sandstedt, B.; Toftgård, R.; Zaphiropoulos, P.G. Mammalian Suppressor-of-Fused modulates nuclear-cytoplasmic shuttling of GLI-1. Nat. Cell Biol. 1999, 1, 312-319. [CrossRef]

121. Shi, Q.; Han, Y.; Jiang, J. Suppressor of fused impedes Ci/Gli nuclear import by opposing Trn/Kap $\beta 2$ in Hedgehog signaling. J. Cell Sci. 2014, 127, 1092-1103. [CrossRef]

122. Szczepny, A.; Wagstaff, K.M.; Dias, M.; Gajewska, K.; Wang, C.; Davies, R.G.; Kaur, G.; Ly-Huynh, J.; Loveland, K.L.; Jans, D.A. Overlapping binding sites for importin $\beta 1$ and suppressor of fused ( $\mathrm{SuFu}$ ) on glioma-associated oncogene homologue 1 (Gli1) regulate its nuclear localization. Biochem. J. 2014, 461, 469-476. [CrossRef] [PubMed]

123. Huntzicker, E.G.; Estay, I.S.; Zhen, H.; Lokteva, L.A.; Jackson, P.K.; Oro, A.E. Dual degradation signals control Gli protein stability and tumor formation. Genes Dev. 2006, 20, 276-281. [CrossRef]

124. Pan, Y.; Bai, C.B.; Joyner, A.L.; Wang, B. Sonic hedgehog Signaling Regulates Gli2 Transcriptional Activity by Suppressing Its Processing and Degradation. Mol. Cell. Biol. 2006, 26, 3365-3377. [CrossRef] [PubMed]

125. Tempé, D.; Casas, M.; Karaz, S.; Blanchet-Tournier, M.-F.; Concordet, J.-P. Multisite Protein Kinase A and Glycogen Synthase Kinase $3 \beta$ Phosphorylation Leads to Gli3 Ubiquitination by SCF $\beta$ TrCP. Mol. Cell. Biol. 2006, 26, 4316-4326. [CrossRef] [PubMed]

126. Wang, B.; Li, Y. Evidence for the direct involvement of TrCP in Gli3 protein processing. Proc. Natl. Acad. Sci. USA 2006, 103, 33-38. [CrossRef] [PubMed] 
127. I Altaba, A.R.; Mas, C.; Stecca, B. The Gli code: An information nexus regulating cell fate, stemness and cancer. Trends Cell Biol. 2007, 17, 438-447. [CrossRef] [PubMed]

128. Matissek, S.J.; Elsawa, S.F. GLI3: A mediator of genetic diseases, development and cancer. Cell Commun. Signal. CCS 2020, 18, 1-20. [CrossRef]

129. Maloverjan, A.; Piirsoo, M.; Kasak, L.; Peil, L.; Østerlund, T.; Kogerman, P. Dual Function of UNC-51-like Kinase 3 (Ulk3) in the Sonic Hedgehog Signaling Pathway. J. Biol. Chem. 2010, 285, 30079-30090. [CrossRef]

130. Antonucci, L.; Di Magno, L.; D'Amico, D.; Manni, S.; Serrao, S.M.; Di Pastena, F.; Bordone, R.; Yurtsever, Z.N.; Caimano, M.; Petroni, M.; et al. Mitogen-activated kinase kinase kinase 1 inhibits hedgehog signaling and medulloblastoma growth through GLI1 phosphorylation. Int. J. Oncol. 2018, 54, 505-514. [CrossRef] [PubMed]

131. Atwood, S.X.; Li, M.; Lee, A.; Tang, J.Y.; Oro, A.E. GLI activation by atypical protein kinase $\mathrm{C} \iota / \lambda$ regulates the growth of basal cell carcinomas. Nat. Cell Biol. 2013, 494, 484-488. [CrossRef]

132. Callahan, C.A.; Ofstad, T.; Horng, L.; Wang, J.K.; Zhen, H.H.; Coulombe, P.A.; Oro, A.E. MIM/BEG4, a Sonic hedgehog-responsive gene that potentiates Gli-dependent transcription. Genes Dev. 2004, 18, 2724-2729. [CrossRef] [PubMed]

133. Wang, Y.; Ding, Q.; Yen, C.-J.; Xia, W.; Izzo, J.G.; Lang, J.-Y.; Li, C.-W.; Hsu, J.L.; Miller, S.A.; Wang, X.; et al. The Crosstalk of mTOR/S6K1 and Hedgehog Pathways. Cancer Cell 2012, 21, 374-387. [CrossRef]

134. Akimaru, H.; Hou, D.-X.; Ishii, S. Drosophila CBP is required for dorsal-dependent twist gene expression. Nat. Genet. 1997, 17, 211-214. [CrossRef]

135. Dai, P.; Akimaru, H.; Tanaka, Y.; Maekawa, T.; Nakafuku, M.; Ishii, S. Sonic Hedgehog-induced Activation of the Gli1Promoter Is Mediated by GLI. J. Biol. Chem. 1999, 274, 8143-8152. [CrossRef]

136. Chan, H.M.; La Thangue, N.B. p300/CBP proteins: HATs for transcriptional bridges and scaffolds. J. Cell Sci. 2001, 114, 2363-2373. [CrossRef]

137. Malatesta, M.; Steinhauer, C.; Mohammad, F.; Pandey, D.P.; Squatrito, M.; Helin, K. Histone Acetyltransferase PCAF Is Required for Hedgehog-Gli-Dependent Transcription and Cancer Cell Proliferation. Cancer Res. 2013, 73, 6323-6333. [CrossRef] [PubMed]

138. Nye, M.D.; Almada, L.L.; Fernandez-Barrena, M.G.; Marks, D.L.; Elsawa, S.F.; Vrabel, A.; Tolosa, E.; Ellenrieder, V.; FernandezZapico, M.E. The Transcription Factor GLI1 Interacts with SMAD Proteins to Modulate Transforming Growth Factor $\beta$-Induced Gene Expression in a p300/CREB-binding Protein-associated Factor (PCAF)-dependent Manner. J. Biol. Chem. 2014, 289, 15495-15506. [CrossRef]

139. Mazzà, D.; Infante, P.; Capalbo, C.; Bellavia, D.; Canettieri, G.; Giannini, G.; Screpanti, I.; Gulino, A.; Di Marcotullio, L.; Colicchia, V.; et al. PCAF ubiquitin ligase activity inhibits Hedgehog/Gli1 signaling in p53-dependent response to genotoxic stress. Cell Death Differ. 2013, 20, 1688-1697. [CrossRef] [PubMed]

140. Infante, P.; Canettieri, G.; Gulino, A.; Di Marcotullio, L. Yin-Yang strands of PCAF/Hedgehog axis in cancer control. Trends Mol. Med. 2014, 20, 416-418. [CrossRef]

141. Safgren, S.L.; Olson, R.L.; Vrabel, A.M.; Almada, L.L.; Marks, D.L.; Hernandez-Alvarado, N.; Gaspar-Maia, A.; Fernandez-Zapico, M.E. The transcription factor GLI1 cooperates with the chromatin remodeler SMARCA2 to regulate chromatin accessibility at distal DNA regulatory elements. J. Biol. Chem. 2020, 295, 8725-8735. [CrossRef] [PubMed]

142. Zhan, X.; Shi, X.; Zhang, Z.; Chen, Y.; Wu, J.I. Dual role of Brg chromatin remodeling factor in Sonic hedgehog signaling during neural development. Proc. Natl. Acad. Sci. USA 2011, 108, 12758-12763. [CrossRef]

143. Bosco-Clément, G.; Zhang, F.; Chen, Z.; Zhou, H.-M.; Li, H.; Mikami, I.; Hirata, T.; Yagui-Beltran, A.; Lui, N.; Do, H.T.; et al. Targeting Gli transcription activation by small molecule suppresses tumor growth. Oncogene 2014, 33, 2087-2097. [CrossRef]

144. Yoon, J.W.; Lamm, M.; Iannaccone, S.; Higashiyama, N.; Leong, K.F.; Iannaccone, P.; Walterhouse, D. p53 modulates the activity of the GLI1 oncogene through interactions with the shared coactivator TAF9. DNA Repair 2015, 34, 9-17. [CrossRef] [PubMed]

145. Mao, J.; Maye, P.; Kogerman, P.; Tejedor, F.J; Toftgard, R.; Xie, W.; Wu, G.; Wu, D. Regulation of Gli1 Transcriptional Activity in the Nucleus by Dyrk. J. Biol. Chem. 2002, 277, 35156-35161. [CrossRef] [PubMed]

146. Coni, S.; Mancuso, A.B.; Di Magno, L.; Sdruscia, G.; Manni, S.; Serrao, S.M.; Rotili, D.; Spiombi, E.; Bufalieri, F.; Petroni, M.; et al. Selective targeting of HDAC1/2 elicits anticancer effects through Gli1 acetylation in preclinical models of SHH Medulloblastoma. Sci. Rep. 2017, 7, 44079. [CrossRef]

147. Tan, Z.; Niu, B.; Tsang, K.Y.; Melhado, I.G.; Ohba, S.; He, X.; Huang, Y.; Wang, C.; McMahon, A.P.; Jauch, R.; et al. Synergistic Co-Regulation and Competition by a SOX9-GLI-FOXA Phasic Transcriptional Network Coordinate Chondrocyte Differentiation Transitions. PLoS Genet. 2018, 14, e1007346. [CrossRef]

148. Tolosa, E.J.; Fernandez-Barrena, M.G.; Iguchi, E.; McCleary-Wheeler, A.L.; Carr, R.M.; Almada, L.L.; Flores, L.F.; Vera, R.E.; Alfonse, G.W.; Marks, D.L.; et al. GLI1/GLI2 functional interplay is required to control Hedgehog/GLI targets gene expression. Biochem. J. 2020, 477, 3131-3145. [CrossRef]

149. Svärd, J.; Henricson, K.H.; Persson-Lek, M.; Rozell, B.; Lauth, M.; Bergström, Å.; Ericson, J.; Toftgård, R.; Teglund, S. Genetic Elimination of Suppressor of Fused Reveals an Essential Repressor Function in the Mammalian Hedgehog Signaling Pathway. Dev. Cell 2006, 10, 187-197. [CrossRef] [PubMed]

150. Liao, H.; Cai, J.; Liu, C.; Shen, L.; Pu, X.; Yao, Y.; Han, B.; Yu, T.; Cheng, S.Y.; Yue, S. Protein phosphatase 4 promotes Hedgehog signaling through dephosphorylation of Suppressor of fused. Cell Death Dis. 2020, 11, 1-14. [CrossRef] 
151. Cherry, A.; Finta, C.; Karlström, M.; Jin, Q.; Schwend, T.; Astorga-Wells, J.; Zubarev, R.; Del Campo, M.; Criswell, A.R.; De Sanctis, D.; et al. Structural basis of SUFU-GLI interaction in human Hedgehog signalling regulation. Acta Crystallogr. Sect. D Biol. Crystallogr. 2013, 69, 2563-2579. [CrossRef]

152. Merchant, M.; Vajdos, F.F.; Ultsch, M.; Maun, H.R.; Wendt, U.; Cannon, J.; Desmarais, W.; Lazarus, R.A.; de Vos, A.M.; de Sauvage, F.J. Suppressor of Fused Regulates Gli Activity through a Dual Binding Mechanism. Mol. Cell. Biol. 2004, 24, 8627-8641. [CrossRef]

153. Zhang, Y.; Fu, L.; Qi, X.; Zhang, Z.; Xia, Y.; Jia, J.; Jiang, J.; Zhao, Y.; Wu, G. Structural insight into the mutual recognition and regulation between Suppressor of Fused and Gli/Ci. Nat. Commun. 2013, 4, 1-12. [CrossRef]

154. Paces-Fessy, M.; Boucher, D.; Petit, E.; Paute-Briand, S.; Blanchet-Tournier, M.-F. The negative regulator of Gli, Suppressor of fused (Sufu), interacts with SAP18, Galectin3 and other nuclear proteins. Biochem. J. 2004, 378, 353-362. [CrossRef] [PubMed]

155. Cheng, S.Y.; Bishop, J.M. Suppressor of Fused represses Gli-mediated transcription by recruiting the SAP18-mSin3 corepressor complex. Proc. Natl. Acad. Sci. USA 2002, 99, 5442-5447. [CrossRef]

156. McCallum, S.A.; Bazan, J.F.; Merchant, M.; Yin, J.; Pan, B.; De Sauvage, F.J.; Fairbrother, W.J. Structure of SAP18: A Ubiquitin Fold in Histone Deacetylase Complex Assembly. Biochemistry 2006, 45, 11974-11982. [CrossRef]

157. Raducu, M.; Fung, E.; Serres, S.; Infante, P.; Barberis, A.; Fischer, R.; Bristow, C.; Thézénas, M.; Finta, C.; Christianson, J.; et al. SCF (Fbxl17) ubiquitylation of Sufu regulates Hedgehog signaling and medulloblastoma development. EMBO J. 2016, 35, 1400-1416. [CrossRef] [PubMed]

158. Lin, C.; Yao, E.; Wang, K.; Nozawa, Y.; Shimizu, H.; Johnson, J.R.; Chen, J.-N.; Krogan, N.J.; Chuang, P.-T. Regulation of Sufu activity by $p 66 \beta$ and Mycbp provides new insight into vertebrate Hedgehog signaling. Genes Dev. 2014, 28, 2547-2563. [CrossRef] [PubMed]

159. Carpenter, R.; Lo, H.-W. Hedgehog pathway and GLI1 isoforms in human cancer. Discov. Med. 2012, 13, $105-113$.

160. Sadam, H.; Liivas, U.; Kazantseva, A.; Pruunsild, P.; Kazantseva, J.; Timmusk, T.; Neuman, T.; Palm, K. GLI2 cell-specific activity is controlled at the level of transcription and RNA processing: Consequences to cancer metastasis. Biochim. Biophys. Acta BBA-Mol. Basis Dis. 2016, 1862, 46-55. [CrossRef]

161. Altaba, A.R.I. Combinatorial Gli Gene Function in Floor Plate and Neuronal Inductions by Sonic Hedgehog. Development 1998, 125, 2203-2212. [CrossRef]

162. Stecca, B.; Altaba, A. A GLI1-P53 Inhibitory Loop Controls Neural Stem Cell and Tumour Cell Numbers. EMBO J. 2009, 28, 663-676. [CrossRef]

163. Ali, S.A.; Niu, B.; Cheah, K.S.E.; Alman, B. Unique and overlapping GLI1 and GLI2 transcriptional targets in neoplastic chondrocytes. PLoS ONE 2019, 14, e0211333. [CrossRef]

164. Lichti-Kaiser, K.; ZeRuth, G.; Kang, H.S.; Vasanth, S.; Jetten, A.M. Gli-Similar Proteins: Their Mechanisms of Action, Physiological Functions, and Roles in Disease. Vitam. Horm. 2012, 88, 141-171. [CrossRef]

165. Pearson, R.; Fleetwood, J.; Eaton, S.; Crossley, M.; Bao, S. Krüppel-like transcription factors: A functional family. Int. J. Biochem. Cell Biol. 2008, 40, 1996-2001. [CrossRef]

166. Kim, Y.-S.; Lewandoski, M.; Perantoni, A.O.; Kurebayashi, S.; Nakanishi, G.; Jetten, A.M. Identification of Glis1, a Novel Gli-related, Krüppel-like Zinc Finger Protein Containing Transactivation and Repressor Functions. J. Biol. Chem. 2002, 277, 30901-30913. [CrossRef]

167. Kim, Y.; Nakanishi, G.; Lewandoski, M.; Jetten, A.M. GLIS3, a novel member of the GLIS subfamily of Kruppel-like zinc finger proteins with repressor and activation functions. Nucleic Acids Res. 2003, 31, 5513-5525. [CrossRef]

168. Zhang, F.; Nakanishi, G.; Kurebayashi, S.; Yoshino, K.; Perantoni, A.; Kim, Y.-S.; Jetten, A.M. Characterization of Glis2, a Novel Gene Encoding a Gli-related, Krüppel-like Transcription Factor with Transactivation and Repressor Functions: Roles in Kidney Development and Neurogenesis. J. Biol. Chem. 2002, 277, 10139-10149. [CrossRef]

169. Zhang, F.; Jetten, A.M. Genomic Structure of the Gene Encoding the Human GLI-Related, Krüppel-Like Zinc Finger Protein GLIS2. Gene 2001, 280, 49-57. [CrossRef]

170. Vasanth, S.; ZeRuth, G.; Kang, H.S.; Jetten, A.M. Identification of Nuclear Localization, DNA Binding, and Transactivating Mechanisms of Krüppel-like Zinc Finger Protein Gli-Similar 2 (Glis2). J. Biol. Chem. 2011, 286, 4749-4759. [CrossRef] [PubMed]

171. Bigelow, R.L.H.; Chari, N.S.; Undén, A.B.; Spurgers, K.B.; Lee, S.; Roop, D.R.; Toftgård, R.; McDonnell, T.J. Transcriptional Regulation of bcl-2 Mediated by the Sonic Hedgehog Signaling Pathway through gli-1. J. Biol. Chem. 2004, 279, $1197-1205$. [CrossRef] [PubMed]

172. Bouldin, C.M.; Harfe, B.D. Aberrant FGF signaling, independent of ectopic hedgehog signaling, initiates preaxial polydactyly in Dorking chickens. Dev. Biol. 2009, 334, 133-141. [CrossRef] [PubMed]

173. Duman-Scheel, M.; Weng, L.; Xin, S.; Du, W. Hedgehog regulates cell growth and proliferation by inducing Cyclin D and Cyclin E. Nature 2002, 417, 299-304. [CrossRef]

174. Katoh, Y.; Katoh, M. Hedgehog signaling pathway and gastrointestinal stem cell signaling network (Review). Int. J. Mol. Med. 2006, 18, 1019-1023. [CrossRef] [PubMed]

175. Singh, B.N.; Fu, J.; Srivastava, R.K.; Shankar, S. Hedgehog Signaling Antagonist GDC-0449 (Vismodegib) Inhibits Pancreatic Cancer Stem Cell Characteristics: Molecular Mechanisms. PLoS ONE 2011, 6, e27306. [CrossRef]

176. Teh, M.-T.; Wong, S.-T.; Neill, G.W.; Ghali, L.R.; Philpott, M.P.; Quinn, A.G. FOXM1 is a Downstream Target of Gli1 in Basal Cell Carcinomas. Cancer Res. 2002, 62, 4773-4780. 
177. Katoh, Y.; Katoh, M. Hedgehog Target Genes: Mechanisms of Carcinogenesis Induced by Aberrant Hedgehog Signaling Activation. Curr. Mol. Med. 2009, 9, 873-886. [CrossRef] [PubMed]

178. Bonifas, J.M.; Epstein, E.H.; Pennypacker, S.; Chuang, P.-T.; McMahon, A.P.; Williams, M.; Rosenthal, A.; de Sauvage, F.J. Activation of Expression of Hedgehog Target Genes in Basal Cell Carcinomas. J. Investig. Dermatol. 2001, 116, 739-742. [CrossRef] [PubMed]

179. Javelaud, D.; Alexaki, V.I.; Dennler, S.; Mohammad, K.S.; Guise, T.A.; Mauviel, A. TGF- $\beta$ /SMAD/GLI2 Signaling Axis in Cancer Progression and Metastasis: Figure. Cancer Res. 2011, 71, 5606-5610. [CrossRef] [PubMed]

180. Pietrobono, S.; Gagliardi, S.; Stecca, B. Non-canonical Hedgehog Signaling Pathway in Cancer: Activation of GLI Transcription Factors Beyond Smoothened. Front. Genet. 2019, 10, 556. [CrossRef]

181. Barnes, E.A.; Kong, M.; Ollendorff, V.; Donoghue, D.J. Patched1 interacts with cyclin B1 to regulate cell cycle progression. EMBO J. 2001, 20, 2214-2223. [CrossRef]

182. Brennan, D.; Chen, X.; Cheng, L.; Mahoney, M.; Riobo, N.A. Noncanonical Hedgehog Signaling. Vitam. Horm. 2012 , 88, 55-72. [CrossRef] [PubMed]

183. Polizio, A.H.; Chinchilla, P.; Chen, X.; Manning, D.R.; Riobo, N.A. Sonic Hedgehog Activates the GTPases Rac1 and RhoA in a Gli-Independent Manner Through Coupling of Smoothened to Gi Proteins. Sci. Signal. 2011, 4, pt7. [CrossRef]

184. Chinchilla, P.; Xiao, L.; Kazanietz, M.G.; Riobo, N.A. Hedgehog proteins activate pro-angiogenic responses in endothelial cells through non-canonical signaling pathways. Cell Cycle 2010, 9, 570-579. [CrossRef]

185. Belgacem, Y.H.; Borodinsky, L.N. Sonic hedgehog signaling is decoded by calcium spike activity in the developing spinal cord. Proc. Natl. Acad. Sci. USA 2011, 108, 4482-4487. [CrossRef]

186. Berridge, M.J. Neuronal Calcium Signaling. Neuron 1998, 21, 13-26. [CrossRef]

187. Komuro, H.; Rakic, P. Intracellular Ca2+ Fluctuations Modulate the Rate of Neuronal Migration. Neuron 1996, 17, $275-285$. [CrossRef]

188. Teperino, R.; Amann, S.; Bayer, M.; McGee, S.; Loipetzberger, A.; Connor, T.; Jaeger, C.; Kammerer, B.; Winter, L.; Wiche, G.; et al. Hedgehog Partial Agonism Drives Warburg-like Metabolism in Muscle and Brown Fat. Cell 2012, 151, 414-426. [CrossRef] [PubMed]

189. Ahmed, S.; Bradshaw, A.-D.; Gera, S.; Dewan, M.Z.; Xu, R. The TGF- $\beta$ /Smad4 Signaling Pathway in Pancreatic Carcinogenesis and Its Clinical Significance. J. Clin. Med. 2017, 6, 5. [CrossRef]

190. Dennler, S.; Andre, J.; Verrecchia, F.; Mauviel, A. Cloning of the Human GLI2 Promoter: Transcriptional Activation by Transforming Growth Factor-Beta via SMAD3/Beta-Catenin Cooperation. J. Biol. Chem. 2009, 284, 31523-31531. [CrossRef]

191. Dennler, S.; André, J.; Alexaki, I.; Li, A.; Magnaldo, T.; Dijke, P.T.; Wang, X.-J.; Verrecchia, F.; Mauviel, A. Induction of Sonic Hedgehog Mediators by Transforming Growth Factor- $\beta$ : Smad3-Dependent Activation of Gli2 and Gli1 Expression In vitro and In vivo. Cancer Res. 2007, 67, 6981-6986. [CrossRef]

192. Ji, Z.; Mei, F.C.; Xie, J.; Cheng, X. Oncogenic KRAS Activates Hedgehog Signaling Pathway in Pancreatic Cancer Cells. J. Biol. Chem. 2007, 282, 14048-14055. [CrossRef]

193. Katz, L.H.; Li, Y.; Chen, J.-S.; Muñoz, N.M.; Majumdar, A.; Chen, J.; Mishra, L. Targeting TGF- $\beta$ signaling in cancer. Expert Opin. Ther. Targets 2013, 17, 743-760. [CrossRef]

194. Magliano, M.P.D.; Sekine, S.; Ermilov, A.; Ferris, J.; Dlugosz, A.A.; Hebrok, M. Hedgehog/Ras interactions regulate early stages of pancreatic cancer. Genes Dev. 2006, 20, 3161-3173. [CrossRef] [PubMed]

195. Meng, X.; Poon, R.; Zhang, X.; Cheah, A.; Ding, Q.; Hui, C.-C.; Alman, B. Suppressor of Fused Negatively Regulates $\beta$-Catenin Signaling. J. Biol. Chem. 2001, 276, 40113-40119. [CrossRef] [PubMed]

196. Nolan-Stevaux, O.; Lau, J.; Truitt, M.L.; Chu, G.C.; Hebrok, M.; Fernández-Zapico, M.E.; Hanahan, D. GLI1 is regulated through Smoothened-independent mechanisms in neoplastic pancreatic ducts and mediates PDAC cell survival and transformation. Genes Dev. 2009, 23, 24-36. [CrossRef] [PubMed]

197. Padua, D.; Massague, J. Roles of TGF $\beta$ in metastasis. Cell Res. 2008, 19, 89-102. [CrossRef] [PubMed]

198. Pelullo, M.; Zema, S.; Nardozza, F.; Checquolo, S.; Screpanti, I.; Bellavia, D. Wnt, Notch, and TGF- $\beta$ Pathways Impinge on Hedgehog Signaling Complexity: An Open Window on Cancer. Front. Genet. 2019, 10, 711. [CrossRef]

199. Pickup, M.; Novitskiy, S.; Moses, H.L. The roles of TGF $\beta$ in the tumour microenvironment. Nat. Rev. Cancer 2013, 13, 788-799. [CrossRef]

200. Rovida, E.; Stecca, B. Mitogen-Activated Protein Kinases and Hedgehog-GLI Signaling in Cancer: A Crosstalk Providing Therapeutic Opportunities? Semin. Cancer Biol. 2015, 35, 154-167. [CrossRef] [PubMed]

201. Seto, M.; Ohta, M.; Asaoka, Y.; Ikenoue, T.; Tada, M.; Miyabayashi, K.; Mohri, D.; Tanaka, Y.; Ijichi, H.; Tateishi, K.; et al. Regulation of the hedgehog signaling by the mitogen-activated protein kinase cascade in gastric cancer. Mol. Carcinog. 2009, 48, 703-712. [CrossRef] [PubMed]

202. Polyak, K.; Weinberg, R.A. Transitions between epithelial and mesenchymal states: Acquisition of malignant and stem cell traits. Nat. Rev. Cancer 2009, 9, 265-273. [CrossRef]

203. Thiery, J.P.; Acloque, H.; Huang, R.Y.-J.; Nieto, M.A. Epithelial-Mesenchymal Transitions in Development and Disease. Cell 2009, 139, 871-890. [CrossRef] 
204. McCleary-Wheeler, A.L.; Paradise, B.D.; Almada, L.L.; Carlson, A.J.; Marks, D.L.; Vrabel, A.; Vera, R.E.; Sigafoos, A.N.; Olson, R.L.; Fernandez-Zapico, M.E. TFII-I-mediated polymerase pausing antagonizes GLI2 induction by TGF $\beta$. Nucleic Acids Res. 2020, 48, 7169-7181. [CrossRef]

205. Samarakkody, A.; Abbas, A.; Scheidegger, A.; Warns, J.; Nnoli, O.; Jokinen, B.; Zarns, K.; Kubat, B.; Dhasarathy, A.; Nechaev, S. RNA polymerase II pausing can be retained or acquired during activation of genes involved in the epithelial to mesenchymal transition. Nucleic Acids Res. 2015, 43, 3938-3949. [CrossRef]

206. Saunders, A.; Core, L.J.; Sutcliffe, C.; Lis, J.T.; Ashe, H.L. Extensive polymerase pausing during Drosophila axis patterning enables high-level and pliable transcription. Genes Dev. 2013, 27, 1146-1158. [CrossRef] [PubMed]

207. Jonkers, I.; Kwak, H.; Lis, J.T. Genome-Wide Dynamics of Pol II Elongation and its Interplay with Promoter Proximal Pausing, Chromatin, and Exons. eLife 2014, 3, e02407. [CrossRef]

208. Min, I.M.; Waterfall, J.; Core, L.J.; Munroe, R.J.; Schimenti, J.; Lis, J.T. Regulating RNA polymerase pausing and transcription elongation in embryonic stem cells. Genes Dev. 2011, 25, 742-754. [CrossRef] [PubMed]

209. Muse, G.W.; Gilchrist, D.; Nechaev, S.; Shah, R.; Parker, J.S.; Grissom, S.F.; Zeitlinger, J.; Adelman, K. RNA polymerase is poised for activation across the genome. Nat. Genet. 2007, 39, 1507-1511. [CrossRef] [PubMed]

210. Nechaev, S.; Adelman, K. Promoter-Proximal Pol II: When Stalling Speeds Things Up. Cell Cycle Georget. Tex 2008, 7, 1539-1544. [CrossRef]

211. Adelman, K.; Lis, J.T. Promoter-Proximal Pausing of RNA Polymerase II: Emerging Roles in Metazoans. Nat. Rev. Genet. 2012, 13, 720-731. [CrossRef]

212. Vos, S.M.; Farnung, L.; Urlaub, H.; Cramer, P. Structure of paused transcription complex Pol II-DSIF-NELF. Nat. Cell Biol. 2018, 560, 601-606. [CrossRef] [PubMed]

213. Hu, M.; Yao, J.; Carroll, D.K.; Weremowicz, S.; Chen, H.; Carrasco, D.; Richardson, A.; Violette, S.; Nikolskaya, T.; Nikolsky, Y.; et al. Regulation of In Situ to Invasive Breast Carcinoma Transition. Cancer Cell 2008, 13, 394-406. [CrossRef] [PubMed]

214. Peng, L.; Yang, C.; Yin, J.; Ge, M.; Wang, S.; Zhang, G.; Zhang, Q.; Xu, F.; Dai, Z.; Xie, L.; et al. TGF- $\beta 2$ Induces Gli1 in a Smad3-Dependent Manner Against Cerebral Ischemia/Reperfusion Injury After Isoflurane Post-conditioning in Rats. Front. Neurosci. 2019, 13, 636. [CrossRef] [PubMed]

215. Mazumdar, T.; DeVecchio, J.; Agyeman, A.; Shi, T.; Houghton, J.A. Blocking Hedgehog Survival Signaling at the Level of the GLI Genes Induces DNA Damage and Extensive Cell Death in Human Colon Carcinoma Cells. Cancer Res. 2011, 71, 5904-5914. [CrossRef] [PubMed]

216. Pierrat, M.-J.; Marsaud, V.; Mauviel, A.; Javelaud, D. Expression of Microphthalmia-associated Transcription Factor (MITF), Which Is Critical for Melanoma Progression, Is Inhibited by Both Transcription Factor GLI2 and Transforming Growth Factor- $\beta$. J. Biol. Chem. 2012, 287, 17996-18004. [CrossRef] [PubMed]

217. Alexaki, V.-I.; Javelaud, D.; van Kempen, L.; Mohammad, K.S.; Dennler, S.; Luciani, F.; Hoek, K.S.; Juàrez, P.; Goydos, J.; Fournier, P.; et al. GLI2-Mediated Melanoma Invasion and Metastasis. J. Natl. Cancer Inst. 2010, 102, 1148-1159. [CrossRef]

218. Johnson, R.W.; Nguyen, M.P.; Padalecki, S.S.; Grubbs, B.G.; Merkel, A.; Oyajobi, B.O.; Matrisian, L.M.; Mundy, G.R.; Sterling, J.A. TGF- $\beta$ Promotion of Gli2-Induced Expression of Parathyroid Hormone-Related Protein, an Important Osteolytic Factor in Bone Metastasis, Is Independent of Canonical Hedgehog Signaling. Cancer Res. 2011, 71, 822-831. [CrossRef]

219. Steg, A.D.; Bevis, K.S.; Katre, A.A.; Ziebarth, A.; Dobbin, Z.C.; Alvarez, R.D.; Zhang, K.; Conner, M.; Landen, C.N. Stem Cell Pathways Contribute to Clinical Chemoresistance in Ovarian Cancer. Clin. Cancer Res. 2012, 18, 869-881. [CrossRef] [PubMed]

220. Fan, Q.; He, M.; Sheng, T.; Zhang, X.; Sinha, M.; Luxon, B.; Zhao, X.; Xie, J. Requirement of TGF $\beta$ Signaling for SMO-mediated Carcinogenesis. J. Biol. Chem. 2010, 285, 36570-36576. [CrossRef]

221. Zhang, J.; Tian, X.-J.; Chen, Y.-J.; Wang, W.; Watkins, S.; Xing, J. Pathway crosstalk enables cells to interpret TGF- $\beta$ duration. NPJ Syst. Biol. Appl. 2018, 4, 18. [CrossRef] [PubMed]

222. Fitzgerald, T.L.; Lertpiriyapong, K.; Cocco, L.; Martelli, A.M.; Libra, M.; Candido, S.; Montalto, G.; Cervello, M.; Steelman, L.; Abrams, S.L.; et al. Roles of EGFR and KRAS and their downstream signaling pathways in pancreatic cancer and pancreatic cancer stem cells. Adv. Biol. Regul. 2015, 59, 65-81. [CrossRef]

223. Pantsar, T. The current understanding of KRAS protein structure and dynamics. Comput. Struct. Biotechnol. J. 2020, 18, 189-198. [CrossRef] [PubMed]

224. Zenonos, K.; Kyprianou, K. RAS signaling pathways, mutations and their role in colorectal cancer. World J. Gastrointest. Oncol. 2013, 5, 97-101. [CrossRef] [PubMed]

225. Riobo, N.A.; Lu, K.; Ai, X.; Haines, G.M.; Emerson, C.P., Jr. Phosphoinositide 3-kinase and Akt are essential for Sonic Hedgehog signaling. Proc. Natl. Acad. Sci. USA 2006, 103, 4505-4510. [CrossRef]

226. Brannon, M.; Gomperts, M.; Sumoy, L.; Moon, R.T.; Kimelman, D. A Beta-Catenin/XTcf-3 Complex Binds to the Siamois Promoter to Regulate Dorsal Axis Specification in Xenopus. Genes Dev. 1997, 11, 2359-2370. [CrossRef]

227. He, X.; Semenov, M.; Tamai, K.; Zeng, X. LDL receptor-related proteins 5 and 6 in Wnt/ $\beta$-catenin signaling:Arrows point the way. Development 2004, 131, 1663-1677. [CrossRef]

228. Macdonald, B.T.; Tamai, K.; He, X. Wnt/ $\beta$-Catenin Signaling: Components, Mechanisms, and Diseases. Dev. Cell 2009, 17, 9-26. [CrossRef] [PubMed]

229. Li, J.; Mizukami, Y.; Zhang, X.; Jo, W.-S.; Chung, D.C. Oncogenic K-ras Stimulates Wnt Signaling in Colon Cancer Through Inhibition of GSK-3ß. Gastroenterology 2005, 128, 1907-1918. [CrossRef] 
230. Song, L.; Li, Z.-Y.; Liu, W.-P.; Zhao, M.-R. Crosstalk between Wnt/ $\beta$-catenin and Hedgehog/Gli signaling pathways in colon cancer and implications for therapy. Cancer Biol. Ther. 2014, 16, 1-7. [CrossRef] [PubMed]

231. Ulloa, F.; Itasaki, N.; Briscoe, J. Inhibitory Gli3 Activity Negatively Regulates Wnt/ $\beta$-Catenin Signaling. Curr. Biol. 2007, 17, 545-550. [CrossRef]

232. Stenson, P.D.; Ball, E.V.; Mort, M.; Phillips, A.D.; Shiel, J.A.; Thomas, N.S.; Abeysinghe, S.; Krawczak, M.; Cooper, D.N. Human Gene Mutation Database (HGMD®): 2003 Update. Hum. Mutat. 2003, 21, 577-581. [CrossRef] [PubMed]

233. National Library of Medicine Medline Plus. Available online: https:/ / medlineplus.gov (accessed on 18 June 2021 ).

234. McKusick-Nathans Institute of Genetic Medicine, Johns Hopkins University Online Mendelian Inheritance in Man, OMIM. Available online: https:/ / omim.org/ (accessed on 18 June 2021).

235. Gupta, S.; Takebe, N.; LoRusso, P. Review: Targeting the Hedgehog Pathway in Cancer. Ther. Adv. Med. Oncol. 2010, 2, 237-250. [CrossRef] [PubMed]

236. Tian, D.-Y.; Cheng, W.-T.; Xu, K.; Zhang, Z.-G.; Liu, L.-J.; Chen, Y. Role of Hedgehog signaling pathway in proliferation and invasiveness of hepatocellular carcinoma cells. Int. J. Oncol. 2009, 34, 829-836. [CrossRef] [PubMed]

237. Jiang, W.G.; Ye, L.; Ruge, F.; Sun, P.-H.; Sanders, A.J.; Ji, K.; Lane, J.; Zhang, L.; Satherley, L.; Weeks, H.P.; et al. Expression of Sonic Hedgehog $(\mathrm{SHH})$ in human lung cancer and the impact of YangZheng XiaoJi on SHH-mediated biological function of lung cancer cells and tumor growth. Anticancer Res. 2015, 35, 1321-1331. [PubMed]

238. Karhadkar, S.S.; Bova, G.S.; Abdallah, N.; Dhara, S.; Gardner, D.R.; Maitra, A.; Isaacs, J.T.; Berman, D.M.; Beachy, P.A. Hedgehog signalling in prostate regeneration, neoplasia and metastasis. Nat. Cell Biol. 2004, 431, 707-712. [CrossRef] [PubMed]

239. Klieser, S.S.E.; Swierczynski, S.; Mayr, C.; Ger, J.S.; Schmidt, J.; Neureiter, D.; Kiesslich, T.; Illig, R. Differential Role of Hedgehog Signaling in Human Pancreatic (Patho-) physiology: An Up to Date Review. World J. Gastrointest. Pathophysiol. 2016, 7, 199-210. [CrossRef] [PubMed]

240. Maréchal, R.; Bachet, J.-B.; Calomme, A.; Demetter, P.; Delpero, J.R.; Svrcek, M.; Cros, J.; Bardier-Dupas, A.; Puleo, F.; Monges, G.G.; et al. Sonic Hedgehog and Gli1 Expression Predict Outcome in Resected Pancreatic Adenocarcinoma. Clin. Cancer Res. 2015, 21, 1215-1224. [CrossRef]

241. Kasiri, S.; Chen, B.; Wilson, A.N.; Reczek, A.; Mazambani, S.; Gadhvi, J.; Noel, E.; Marriam, U.; Mino, B.; Lu, W.; et al. Stromal Hedgehog Pathway Activation by IHH Suppresses Lung Adenocarcinoma Growth and Metastasis by Limiting Reactive Oxygen Species. Oncogene 2020, 39, 3258-3275. [CrossRef]

242. Lee, J.J.; Perera, R.M.; Wang, H.; Wu, D.-C.; Liu, X.S.; Han, S.; Fitamant, J.; Jones, P.D.; Ghanta, K.; Kawano, S.; et al. Stromal response to Hedgehog signaling restrains pancreatic cancer progression. Proc. Natl. Acad. Sci. USA 2014, 111, E3091-E3100. [CrossRef]

243. Tian, H.; Callahan, C.A.; DuPree, K.J.; Darbonne, W.C.; Ahn, C.P.; Scales, S.J.; de Sauvage, F.J. Hedgehog signaling is restricted to the stromal compartment during pancreatic carcinogenesis. Proc. Natl. Acad. Sci. USA 2009, 106, 4254-4259. [CrossRef]

244. Huq, A.J.; Walsh, M.; Rajagopalan, B.; Finlay, M.; Trainer, A.H.; Bonnet, F.; Sévenet, N.; Winship, I.M. Mutations in SUFU and PTCH1 genes may cause different cutaneous cancer predisposition syndromes: Similar, but not the same. Fam. Cancer 2018, 17, 601-606. [CrossRef]

245. Urman, N.M.; Mirza, A.; Atwood, S.X.; Whitson, R.J.; Sarin, K.Y.; Tang, J.Y.; Oro, A.E. Tumor-Derived Suppressor of Fused Mutations Reveal Hedgehog Pathway Interactions. PLoS ONE 2016, 11, e0168031. [CrossRef] [PubMed]

246. Aavikko, M.; Li, S.-P.; Saarinen, S.; Alhopuro, P.; Kaasinen, E.; Morgunova, E.; Li, Y.; Vesanen, K.; Smith, M.J.; Evans, G.; et al. Loss of SUFU Function in Familial Multiple Meningioma. Am. J. Hum. Genet. 2012, 91, 520-526. [CrossRef] [PubMed]

247. Mann, K.; Magee, J.; Guillaud-Bataille, M.; Blondel, C.; Paillerets, B.B.-D.; Yeatman, J.; Winship, I. Multiple Skin Hamartomata: A Possible Novel Clinical Presentation of SUFU Neoplasia Syndrome. Fam. Cancer 2015, 14, 151-155. [CrossRef] [PubMed]

248. Skaro, M.; Nanda, N.; Gauthier, C.; Felsenstein, M.; Jiang, Z.; Qiu, M.; Shindo, K.; Yu, J.; Hutchings, D.; Javed, A.A.; et al. Prevalence of Germline Mutations Associated with Cancer Risk in Patients with Intraductal Papillary Mucinous Neoplasms. Gastroenterology 2019, 156, 1905-1913. [CrossRef]

249. Xu, Q.; Gao, J.; Li, Z. Identification of a novel alternative splicing transcript variant of the suppressor of fused: Relationship with lymph node metastasis in pancreatic ductal adenocarcinoma. Int. J. Oncol. 2016, 49, 2611-2619. [CrossRef]

250. Szczepny, A.; Rogers, S.; Jayasekara, W.S.N.; Park, K.; McCloy, R.A.; Cochrane, C.R.; Ganju, V.; Cooper, W.A.; Sage, J.; Peacock, C.D.; et al. The Role of Canonical and Non-Canonical Hedgehog Signaling in Tumor Progression in a Mouse Model of Small Cell Lung Cancer. Oncogene 2017, 36, 5544-5550. [CrossRef] [PubMed]

251. Liu, Z.; Li, T.; Reinhold, M.I.; Naski, M.C. MEK1-RSK2 Contributes to Hedgehog Signaling by Stabilizing GLI2 Transcription Factor and Inhibiting Ubiquitination. Oncogene 2012, 33, 65-73. [CrossRef] [PubMed]

252. Stecca, B.; Mas, C.; Clement, V.; Zbinden, M.; Correa, R.; Piguet, V.; Beermann, F.; Altaba, A.R.I. Melanomas Require Hedgehog-Gli Signaling Regulated by Interactions between Gli1 and the RAS-MEK/AKT Pathways. Proc. Natl. Acad. Sci. USA 2007, 104, 5895-5900. [CrossRef] [PubMed]

253. Po, A.; Silvano, M.; Miele, E.; Capalbo, C.; Eramo, A.; Salvati, V.; Todaro, M.; Besharat, Z.; Catanzaro, G.; Cucchi, D.; et al. Noncanonical GLI1 Signaling Promotes Stemness Features and In Vivo Growth in Lung Adenocarcinoma. Oncogene 2017, 36, 4641-4652. [CrossRef] [PubMed]

254. Mazumdar, T.; DeVecchio, J.; Agyeman, A.; Shi, T.; Houghton, J.A. The GLI Genes as the Molecular Switch in Disrupting Hedgehog Signaling in Colon Cancer. Oncotarget 2011, 2, 638-645. [CrossRef] 
255. Tang, Y.-A.; Chen, Y.-F.; Bao, Y.; Mahara, S.; Yatim, S.M.J.M.; Oguz, G.; Lee, P.L.; Feng, M.; Cai, Y.; Tan, E.Y.; et al. Hypoxic Tumor Microenvironment Activates GLI2 via HIF- $1 \alpha$ and TGF- $\beta 2$ to Promote Chemoresistance in Colorectal Cancer. Proc. Natl. Acad. Sci. USA 2018, 115, E5990-E5999. [CrossRef] [PubMed]

256. Yoo, Y.A.; Kang, M.H.; Kim, J.S.; Oh, S.C. Sonic Hedgehog Signaling Promotes Motility and Invasiveness of Gastric Cancer Cells Through TGF-Mediated Activation of the ALK5-Smad 3 Pathway. Carcinogenesis 2007, 29, 480-490. [CrossRef] [PubMed]

257. Janssen, K.; Alberici, P.; Fsihi, H.; Gaspar, C.; Breukel, C.; Franken, P.; Rosty, C.; Abal, M.; El Marjou, F.; Smits, R.; et al. APC and Oncogenic KRAS Are Synergistic in Enhancing Wnt Signaling in Intestinal Tumor Formation and Progression. Gastroenterology 2006, 131, 1096-1109. [CrossRef]

258. Maeda, O.; Kondo, M.; Fujita, T.; Usami, N.; Fukui, T.; Shimokata, K.; Ando, T.; Goto, H.; Sekido, Y. Enhancement of GLI1Transcriptional Activity by $\beta$-Catenin in Human Cancer Cells. Oncol. Rep. 2006, 16, 91-96. [CrossRef]

259. Pietrobono, S.; Santini, R.; Gagliardi, S.; Dapporto, F.; Colecchia, D.; Chiariello, M.; Leone, C.; Valoti, M.; Manetti, F.; Petricci, E.; et al. Targeted Inhibition of Hedgehog-GLI Signaling by Novel Acylguanidine Derivatives Inhibits Melanoma Cell Growth by Inducing Replication Stress and Mitotic Catastrophe. Cell Death Dis. 2018, 9, 1-16. [CrossRef] [PubMed]

260. Xie, H.; Paradise, B.D.; Ma, W.W.; Fernandez-Zapico, M.E. Recent Advances in the Clinical Targeting of Hedgehog/GLI Signaling in Cancer. Cells 2019, 8, 394. [CrossRef]

261. Dummer, R.; Guminski, A.; Gutzmer, R.; Dirix, L.; Lewis, K.D.; Combemale, P.; Herd, R.M.; Kaatz, M.; Loquai, C.; Stratigos, A.J.; et al. The 12-Month Analysis from Basal Cell Carcinoma Outcomes with LDE225 Treatment (BOLT): A Phase II, Randomized, Double-Blind Study of Sonidegib in Patients with Advanced Basal Cell Carcinoma. J. Am. Acad. Dermatol. 2016, 75, 113-125.e5. [CrossRef] [PubMed]

262. Lorusso, P.M.; Rudin, C.; Reddy, J.C.; Tibes, R.; Weiss, G.J.; Borad, M.J.; Hann, C.L.; Brahmer, J.R.; Chang, I.; Darbonne, W.C.; et al. Phase I Trial of Hedgehog Pathway Inhibitor Vismodegib (GDC-0449) in Patients with Refractory, Locally Advanced or Metastatic Solid Tumors. Clin. Cancer Res. 2011, 17, 2502-2511. [CrossRef]

263. Martinelli, G.; Oehler, V.G.; Papayannidis, C.; Courtney, R.; Shaik, M.N.; Zhang, X.; O'Connell, A.; McLachlan, K.R.; Zheng, X.; Radich, J.; et al. Treatment with PF-04449913, an Oral Smoothened Antagonist, in Patients with Myeloid Malignancies: A Phase 1 Safety and Pharmacokinetics Study. Lancet Haematol. 2015, 2, e339-e346. [CrossRef]

264. Pietanza, M.C.; Litvak, A.M.; Varghese, A.M.; Krug, L.M.; Fleisher, M.; Teitcher, J.B.; Holodny, A.; Sima, C.S.; Woo, K.M.; $\mathrm{Ng}$, K.K.; et al. A Phase I Trial of the Hedgehog Inhibitor, Sonidegib (LDE225), in Combination with Etoposide and Cisplatin for the Initial Treatment of Extensive Stage Small Cell Lung Cancer. Lung Cancer 2016, 99, 23-30. [CrossRef] [PubMed]

265. Rodon, J.; Tawbi, H.A.; Thomas, A.L.; Stoller, R.G.; Turtschi, C.P.; Baselga, J.; Sarantopoulos, J.; Mahalingam, D.; Shou, Y.; Moles, M.A.; et al. A Phase I, Multicenter, Open-Label, First-in-Human, Dose-Escalation Study of the Oral Smoothened Inhibitor Sonidegib (LDE225) in Patients with Advanced Solid Tumors. Clin. Cancer Res. 2014, 20, 1900-1909. [CrossRef]

266. Sekulic, A.; Migden, M.R.; Oro, A.E.; Dirix, L.; Lewis, K.D.; Hainsworth, J.D.; Solomon, J.A.; Yoo, S.; Arron, S.T.; Friedlander, P.A.; et al. Efficacy and Safety of Vismodegib in Advanced Basal-Cell Carcinoma. N. Engl. J. Med. 2012, 366, 2171-2179. [CrossRef]

267. Pricl, S.; Cortelazzi, B.; Col, V.D.; Marson, D.; Laurini, E.; Fermeglia, M.; Licitra, L.; Pilotti, S.; Bossi, P.; Perrone, F. Smoothened (SMO) Receptor Mutations Dictate Resistance to Vismodegib in Basal Cell Carcinoma. Mol. Oncol. 2014, 9, 389-397. [CrossRef] [PubMed]

268. Sharpe, H.J.; Pau, G.; Dijkgraaf, G.J.; Basset-Seguin, N.; Modrusan, Z.; Januario, T.; Tsui, V.; Durham, A.B.; Dlugosz, A.A.; Haverty, P.M.; et al. Genomic Analysis of Smoothened Inhibitor Resistance in Basal Cell Carcinoma. Cancer Cell 2015, 27, 327-341. [CrossRef]

269. Lauth, M.; Bergström, Å.; Shimokawa, T.; Toftgård, R. Inhibition of GLI-mediated transcription and tumor cell growth by small-molecule antagonists. Proc. Natl. Acad. Sci. USA 2007, 104, 8455-8460. [CrossRef]

270. Infante, P.; Mori, M.; Alfonsi, R.; Ghirga, F.; Aiello, F.; Toscano, S.; Ingallina, C.; Siler, M.; Cucchi, D.; Po, A.; et al. Gli1/ DNA Interaction is a Druggable Target for Hedgehog-Dependent Tumors. EMBO J. 2014, 34, 200-217. [CrossRef]

271. Hyman, J.M.; Firestone, A.J.; Heine, V.M.; Zhao, Y.; Ocasio, C.A.; Han, K.; Sun, M.; Rack, P.G.; Sinha, S.; Wu, J.J.; et al. SmallMolecule Inhibitors Reveal Multiple Strategies for Hedgehog Pathway Blockade. Proc. Natl. Acad. Sci. USA 2009, 106, 14132-14137. [CrossRef]

272. Kim, J.; Lee, J.J.; Gardner, D.; Beachy, P.A. Arsenic Antagonizes the Hedgehog Pathway by Preventing Ciliary Accumulation and Reducing Stability of the Gli2 Transcriptional Effector. Proc. Natl. Acad. Sci. USA 2010, 107, 13432-13437. [CrossRef] [PubMed]

273. Beauchamp, E.M.; Ringer, L.; Bulut, G.; Sajwan, K.P.; Hall, M.D.; Lee, Y.-C.; Peaceman, D.; Özdemirli, M.; Rodriguez, O.; Macdonald, T.J.; et al. Arsenic Trioxide Inhibits Human Cancer Cell Growth and Tumor Development in Mice by Blocking Hedgehog/GLI Pathway. J. Clin. Investig. 2011, 121, 148-160. [CrossRef] 